\title{
SWOT Analysis of the Innovation System in Bosnia and Herzegovina
}

\author{
Miloš Trifković* \\ Dženana Husremović**
}

\begin{abstract}
The current global position of Bosnia and Herzegovina confirms the findings of previous research that in our country there is no single or at least harmonized and efficient innovation system, appropriate to the needs of the development of knowledge society and the knowledge economy. The first steps in determining the reasons for this situation are SWOT analyses of the position and role of the innovation system within the general strategic and sectorial research and technology transfer planning. The paper discusses the most important results of matrices obtained and compares them with the findings of our latest research. The first result is a concise SWOT matrix of the innovation system. The results of the elaboration of individual factors we present in a detailed SWOT matrix based on elements of strength. This matrix also showed that uniform and stabilized higher education is the most important element of the strength of the innovation system. Therefore, the paper specifically discusses characteristics of universities as subjects of the innovation system.
\end{abstract}

Key words: Bosnia and Herzegovina, knowledge society and economy, innovation system, SWOT analysis of innovation system, general development strategies, sectorial strategies of innovation system development, universities as subjects of the innovation system

\section{Introductory Notes}

\section{Innovation system and the global economic position of Bosnia and Herzegovina}

Innovation system is a complex social subsystem created by the interaction of subjects in the processes of creation, application, distribution and dissemination of scientifically based knowledge in order to achieve goals set by society. ${ }^{1}$ In par-

\footnotetext{
${ }^{*}$ Full member of the Academy of Sciences and Arts of Bosnia and Herzegovina. E-mail: iucomt@yahoo.com

${ }^{* *}$ Ph.D., Faculty for Philosophy of University of Sarajevo, Vice-Rector for Education of University of Sarajevo. E-mail: dzenana.husremovic@ff.unsa.ba

${ }^{1}$ Trifković, 2020a: 41, see also Trifković, 2020b: 40-41.
} 
allel, the basic elements of innovation systems at the national or supranational level are the same: resources, subjects and regulatory systems. The appearance of the elements, their mutual ties, the way of functioning of the overall innovation system and its relations with other subsystems depend on the historical and current, external and internal circumstances of each society. The same factors determine the system of goals. In modern conditions, the most general theoretical goal of the innovation system is the creation and further development of the knowledge society and knowledge economy as an instrument for raising individual and general well-being, primarily within the community. Hierarchically lower goals are determined according to the pragmatic requirement of raising the competitiveness of the national economy. Therefore, the tasks, structure, mode of operation and results of a particular innovation system ultimately depend on the structure of the state and the degree of overall development of society. ${ }^{2}$ This pattern is also visible in the case of Bosnia and Herzegovina.

For the purposes of this paper, we may summarize the structure of the state to its legal system. A description and critical analysis of the constitutional and legal regulations and their unsatisfactory impact on the state of the innovation system of Bosnia and Herzegovina already exist. ${ }^{3}$ Poor normative and actual regulation of the innovation system is both a consequence and a cause of unsatisfactory development of the Bosnian-Herzegovinian society, the state and the economy, as well as of the weak position of Bosnia and Herzegovina on the global playfield. There are plenty of arguments for such a view. In the global synthetic indices of development and competitiveness of countries over the last ten years, Bosnia and Herzegovina, as a rule, occupies a place in the lower half of the countries covered by the ranking ${ }^{4}-$ with exception in

\footnotetext{
${ }^{2}$ For an extraordinary illustration of this thesis, instructive for B\&H as well, see Radošević \& Lepori, 2009: 659-666.

${ }^{3}$ On constitutional system of B\&H see Trifković. 2020b: 83 - 95 and Trifković, 2020a: 44 - 48. For comparative overview of the most important legal provisions of all three levels of government in B\&H see Trifković, 2020b: 109 - 120 and Trifković, 2020b: $173-186$.

${ }^{4}$ One of the most general indicators of development is GDP per capita calculated according to the purchasing power parity (PPP). According to the World Bank ranking, in 2019 Bosnia and Herzegovina ranked 96th out of 189 countries. In the same year, the UN ranked B\&H 95th out of 193 countries. According to Wikipedia, in $2021 \mathrm{~B} \& \mathrm{H}$ is ranked 92nd out of 141 countries. This is a better ranking than in 2016 (107) and 2017-18 (103). These data are indicative even when taking into account relevant objections to the WEF methodology, and changes in the ranking target and selection of indicators for 2019, according to Schwab, 2019. Cornell University Global Innovation Index (GII) and WIPO in 2020 rank B\&H in 74th place among 131 countries, which is an improvement of two places compared to 2019
} 
terms of human capital. No more favourable for us is the World Bank data on indicators of science and technology development in the period 2010-2018. ${ }^{5}$ Their research shows that Bosnia and Herzegovina lags behind not only the world, Europe and Central Asia, but also the countries that emerged in the process of dissolution of Yugoslavia from its most underdeveloped republics. ${ }^{6}$ Therefore, it is not surprising that the World Economic Forum in its 20172018 Competitiveness Report classified Bosnia and Herzegovina into the group of countries that base their development on efficiency in the use of resources, not on innovation. ${ }^{7}$ Obviously, the process of intensive creation of a knowledge society and knowledge economy in our country is just beginning. ${ }^{8}$

The reasons for the unsatisfactory state of the innovation system and the poor results of the economic and social ${ }^{9}$ competitiveness of Bosnia and Herzegovina are mostly of internal provenance and systemic character. They can be summarized as a development-inappropriate treatment of the country's innovation system. In other words, the innovation system of Bosnia and Herzegovina, within the society and the state it serves, operates in an unfavourable social, political, economic and legal environment. This situation requires an analysis of the state and possibilities of the innovation system to overcome the existing situation.

\section{Methodological determinants}

The current global position of Bosnia and Herzegovina confirms the findings of previous research that "in our country there is no single or harmonized

and four places according to the ranking for 2018. However, even with the aforementioned improvements in placements, B\&H ranks 38th among 39 economies in Europe - a penultimate place according to the World Intellectual Property Organization, 2020.

${ }^{5}$ See World Bank data (2021).

${ }^{6}$ Trifković, 2020a: 55.

${ }^{7}$ Schwab, 2017:320.

${ }^{8}$ On conditions and issues of development which lead former socialist countries into the group of countries whose economy is driven by efficiency and innovation; see Radošević, 2011. ${ }^{9}$ Despite having only 3.5 million inhabitants, on 21 May, 2021, Bosnia and Herzegovina was ranked 45th on the world list by the absolute number of deaths from COVID 19 according to Statista (2021). In addition, data is available which reports that only 76,311 citizens in Bosnia and Herzegovina were vaccinated with the first dose by that date. Data on the number of vaccinated in the Republic of Croatia and the Republic of Serbia are still unknown, according to Babić, 2021. 
and efficient innovation system, appropriate to social needs." 10 Therefore, the main problem of this paper is to identify the most important strengths and weaknesses, which, in conjunction with opportunities and threats, shape the innovation system in Bosnia and Herzegovina and determine its potential for the development of society as a whole. In the current situation, the main goal of the research must be to point out the elements of the innovation system that essentially determine its stagnation or development dynamics, and thus the movement of Bosnia and Herzegovina towards a knowledge society and knowledge economy. The primary hypothesis is: the current position of the innovation system is convincingly determined by weaknesses that limit not only its development, but also the development of Bosnia and Herzegovina. In accordance with the stated main assumption, the dominant subject of research will be the innovation system.

The presented methodological determinants impose an interdisciplinary approach to research. Procedures characteristic for economic, legal and political sciences dominate. The topic and the main problem of the paper require a brief review only of the specifics of the application of SWOT analysis.

\section{Notes on how to use SWOT analysis}

SWOT analysis is a method of strategic management that identifies and cross-examines current and future ${ }^{11}$ internal strengths and weaknesses of a subject or social (sub)system, as well as opportunities and threats from the environment. It appeared in the seventies of the last century. ${ }^{12}$ It was primarily used to determine company's market position, and then it was extended to other areas. ${ }^{13}$ The increased domain of application of SWOT analysis and its derivative TOWS matrix has resulted in more and more frequent connection of these instruments with other methodological procedures of strategic environmental analysis. ${ }^{14}$ Since 2017, in Bosnia and Herzegovina, SWOT matrix is predominantly tied to the PESTEL method.

In the application to the innovation system in general, and in Bosnia and Herzegovina in particular, the SWOT analysis shows some characteristics

\footnotetext{
${ }^{10}$ Trifković, 2020b: 69. This conclusion was, unfortunately, confirmed by the research of the actual state of innovation system in the territory of FB\&H. See Kremić \& Trifković, 2020.

${ }^{11}$ Fleisher \& Bensoussan, 2007: 54-77 and Fleisher \& Bensoussan, 2007: 87-103

${ }^{12}$ Ibidem

${ }^{13}$ Božac, 2008: 20-23

${ }^{14}$ Božac, 2008: 24 -27. and Fleisher \& Bensoussan, 2015
} 
conditioned by the subject of research. First, it has a macro character that requires that each of the four SWOT factors be determined while taking into account a large number of elements of domestic and international provenance. It is not always possible to draw a clear line between internal and external factors, between national and global, and between existing and emerging elements. Errors in each of the three domains are dangerous, especially in the operationalization of the international component of the strategy and the development of strategic scenarios for the development of the innovation system. Second, certain factors consist of a large number of generally complex elements, which imposes the need for their compression. Such procedure gives each element, as well as the SWOT analysis factor, a synthetic character. Increased compression measure creates a threat of impoverishment of the content of certain elements and factors. In the next step, a reductionist approach makes it difficult to determine the impact of the innovation system on the acceleration, stagnation or slowdown of the overall development of Bosnia and Herzegovina. ${ }^{15}$ Third, almost none of the elements of any factor of the innovation system SWOT analysis in practice appear in pure form and with unambiguous effects. Therefore, determining the content of specific elements, their classification by factors of SWOT analysis and the measure of the impact on the innovation system is always to a significant extent a result of individual or group assessment. Therefore, the conclusion is that, even in the research of the innovation system, it is not possible to avoid the objection of subjectivism, which generally relativizes the value of the results of the SWOT analysis. ${ }^{16}$ However, the advantages of SWOT analysis are such that, regardless of methodological problems, it is regularly used in designing of development strategies in Bosnia and Herzegovina.

\footnotetext{
${ }^{15}$ For warning against this threat see Nikolić, s.a. where it is stated that SWOT analysis "has a tendency to overgeneralize situation by classifying environment factors into the categories in which they don't necessarily fully fit."

${ }^{16}$ See Fleisher \& Bensoussan, 2007: 94
} 


\section{Swot Analysis of the Innovation System in Development Strategies in Bosnia and Herzegovina}

\section{Relationship of strategic development planning in Bosnia and Herzegovina towards SWOT analysis}

The basic contradictions of the strategic development planning system in Bosnia and Herzegovina, including the development of the innovation system, have a constitutional character. ${ }^{17}$ The first is the contrast between the uniqueness of the territorial, ${ }^{18}$ economic and social space ${ }^{19}$ of Bosnia and Herzegovina and the extremely large competencies of the lower levels of political-territorial organization in relation to higher levels. Its ultimate expression is the constitutional presumption that the lower levels of state organization have all the competencies that are not explicitly given to the higher political-territorial unit. ${ }^{20}$ The second contrast is the limitation of the exclusive competencies of the state of Bosnia and Herzegovina and its institutions to a relatively small number of economic functions, which are predominantly of international character, ${ }^{21}$ without the existence of internal mechanisms for independent realization of assumed obligations and rights with a foreign element. To illustrate the ultimate consequences of this contradiction, we cite the Decision of the Council of Ministers on the system of coordination of the European integration process in Bosnia and Herzegovina. ${ }^{22}$ This act, by prescribing the methods of horizontal and vertical coordination, includes all lower levels of government of $\mathrm{B} \& \mathrm{H}$ in the decision-making on the issues of joining the European Union and thus de facto gives them the right to exercise

\footnotetext{
${ }^{17}$ Overview of constitutional solutions in Bosnia and Herzegovina, relevant to the innovation system, see Trifković, 2020b: 83. - 91 .

${ }^{18}$ See art. I, par. 1 of the Constitution of Bosnia and Herzegovina

${ }^{19}$ See p. 4 of the Preamble and art. I. 4 of the Constitution of Bosnia and Herzegovina

${ }^{20}$ Art. 3, 1.a) of the Constitution of Bosnia and Herzegovina: "All governmental functions and powers not expressly assigned in this Constitution to the institutions of Bosnia and Herzegovina shall be those of the Entities." Evolution of constitutional law has modified the "constitutional reality" in this and other fields (see: Steiner, 2010: 529 and onward), but it did not change the basic model of the state's organization.

${ }^{21}$ Art. III.1 of the Constitution of Bosnia and Herzegovina. According to art. III. 5 The state shall assume responsibility for such other matters as are agreed by the entities. It should be noted that responsibilities assigned by this article in essence have a foreign-policy character. ${ }^{22}$ Bosnia and Herzegovina. Council of Ministers (2016)
} 
state competencies in international relations. ${ }^{23}$ These contradictions indirectly affect SWOT analyses for the purposes of strategic planning in our country.

Legal regulation of a uniform system of strategic planning in Bosnia and Herzegovina is nearing completion. In accordance with the constitutional competencies, at the state level, it takes place as planning of the institutions of Bosnia and Herzegovina. ${ }^{24}$ Its basis is the strategic framework that includes documents from the B\&H Presidency, the Parliamentary Assembly and the Council of Ministers Based on the established framework, a three-year, i.e. medium- and long-term work programs of the Council of Ministers, ${ }^{25}$ are prepared through special methodology. ${ }^{26}$ For the analysis of the environment, the Methodology Manual especially recommends the SWOT and PESTLE approach. The last publicly available "Strategic Framework for B\&H" for the period 2016-2018 based the analysis of the socio-economic situation on the SWOT matrix. ${ }^{27}$ It is therefore surprising that the sixth draft of the "Mid-Term Work Program 2021-2023" of the Council of Ministers from May $2020^{28}$ does not use this methodology. ${ }^{29}$

The Law on Development Planning and Development Management in the Federation of Bosnia and Herzegovina from $2017^{30}$ (LDP FB\&H) created a unique system of development planning harmonized with the constitutional competencies of the entity and cantons. Ten regulations and one methodology for calculating the development index of local self-government units operationalize its application. ${ }^{31}$ Most interesting for us is the Regulation on the Development of Strategic Documents in the Federation of Bosnia and Herzegovina. ${ }^{32}$ According to its Article 17, the first step in developing a strategic platform is a situational analysis of the internal and external environment

\footnotetext{
${ }^{23}$ Accuracy of the stated conclusion is particularly confirmed by article 3 of the Decision: "Manner of decision making"

${ }^{24}$ Bosnia and Herzegovina. Council of Ministers (2014)

${ }^{25}$ See "Part two - mid-term planning", Bosnia and Herzegovina. Council of Ministers (2014)

${ }^{26}$ Bosnia and Herzegovina. Council of Ministers (2014)

${ }^{27}$ Bosnia and Herzegovina. Council of Ministers of Bosnia and Herzegovina. Directorate for Economic Planning, 2015:30 - 33.

${ }^{28}$ Bosnia and Herzegovina. Council of Ministers of Bosnia and Herzegovina (2020)

${ }^{29}$ Bosnia and Herzegovina. Council of Ministers of Bosnia and Herzegovina, (2010) included the document: "SWOT Analysis of the Development of Economy - Integrated", so we shall refer to it later.

${ }^{30}$ Official Gazette of Federation of Bosnia and Herzegovina No. 32/17

${ }^{31}$ See Federation of Bosnia and Herzegovina. Federal Institute for Development Programming. Regulations (https://www.fzzpr/gov.ba/bos/docs/35/8/uredbe).

${ }^{32}$ Official Gazette of Federation of Bosnia and Herzegovina No. 74/19
} 
"in order to determine the real factors and potentials for the development of the area, or sector, and the limitations and obstacles." Thus, SWOT analysis, at least in the territory of Federation of Bosnia and Herzegovina (FB\&H), has become a legally binding methodology. Practice has confirmed this conclusion. General strategic documents in the Federation of B\&H, completed after the adoption of the LDP FB\&H, regularly contain a SWOT analysis that includes elements of the innovation system. ${ }^{33}$

The basis for strategic development planning in Republika Srpska (RS) is Article 68, para. 1, item 8 of its Constitution, which obliges this entity to, among other things, regulate and provide "basic goals and directions of economic, scientific, technological... development". On that ground, in accordance with the regulations on the functioning of the Government and administrative bodies, a number of sectorial strategies were adopted. The Ministry of Technological Development, Higher Education and Information Society itself lists two adopted strategies and three action plans on its website. ${ }^{34} \mathrm{In}$ mid-April 2021, the National Assembly of the RS ${ }^{35}$ published on its website the draft "Law on Strategic Planning and Development Management in the Republika Srpska". The proposed solutions point to a substantial similarity with the strategic planning system that exists in the FB\&H entity.

With the adoption of the Law on Strategic Planning and Development Management in Republika Srpska, the professional principles of strategic planning will acquire a legal character throughout the country. Among the most important principles are: partnership of all levels of state government with local self-government units, vertical and horizontal coordination, synchronization of planning, complementarity of strategies, and efficiency and effectiveness of planning. The need to respect these principles will influence the way the SWOT analysis is made. First, SWOT analysis will become mandatory and will be used in conjunction with other strategic planning methodologies. Second, when concretizing the elements of each factor, creators of the analysis will have to respect the constitutional competence of the level of

\footnotetext{
${ }^{33}$ Federation of Bosnia and Herzegovina. Government of the Federation of Bosnia and Herzegovina (2021). According to art. 16 par. 5 of the Law on Development Planning, the final decision is made by the Parliament of FB\&H. Overview of the state of works on development of cantonal strategies, mainly for the period 2021-2027 is on the Federal Institute for Development Programming web site (https://www.fzzpr.gov.ba/bs/docs/25/4/kantonalni-strateški -dokumenti)

${ }^{34}$ Republika Srpska. Government of Republika Srpska (2017)

${ }^{35}$ Republika Srpska. National Assembly of Republika Srpska. Materials for the $16^{\text {th }}$ regular session
} 
government for which the strategy is being worked out. Third, respect for the principles of strategic planning will certainly affect the choice of elements that make up each factor of SWOT analysis, the content given to the selected elements and the precision to the formulations that define the elements.

Elements of the SWOT matrix of the innovation system in strategic development documents in Bosnia and Herzegovina

The representation of the elements of the innovation system in SWOT analyses of general strategic development documents is an important indicator of the attitude of the bearers of planning and political decision-making in Bosnia and Herzegovina towards the knowledge society and knowledge economy. To determine the treatment of the innovation system in strategic plans, we examined SWOT analyses in a total of 13 preparatory materials, proposals and general development strategies, regardless of their legal validity. This research covers the entire territory of Bosnia and Herzegovina over - for our conditions - a relatively long period from 2010 to 2027 . We have taken over the elements of the innovation system SWOT analysis which some documents, mostly newer, state according to the PESTEL method, regardless of the area in which they are located and the frequency of occurrence. The significance of an individual element was first determined in and of itself, and then in relation to other elements of the same and other factors of the SWOT analysis. In doing so, we had in mind that, due to the different competencies of individual subjects of strategic planning, content analysis in this case can be useful only to a limited extent. Attached Table 1: "Elements of the innovation system in SWOT analyses of development documents" offers total results. In essence, Table 1 is the SWOT matrix of the innovation system of Bosnia and Herzegovina, extrapolated from the existing documents of general strategic planning in the country. Despite all the methodological limitations, the tabular overview provides several basic conclusions about the position of the innovation system in Bosnia and Herzegovina. Following are the most important ones.

First, the factors of the extrapolated SWOT matrix of the innovation system have the following number of elements: strengths - 10, weaknesses - 16, opportunities - 7 and threats -8 . This confirms the dominance of weaknesses, characteristic of general strategic documents and sectorial strategies of innovation system development. Among the elements of strength, those concerning the system and quality of higher education dominate. It is interesting that 
all three levels of government agree on this element. ${ }^{36}$ This places Bosnia and Herzegovina among the countries in which absolutely dominates state funding of science, almost exclusively through universities. ${ }^{37}$ In weaknesses, leading are those of a systemic nature. Out of nine of them, four should be mentioned: insufficient legal and strategic framework, un-incentive tax and customs policy, weak connection between the public, economic and academic sector (the Triple Helix) ${ }^{38}$, and insufficient copyright protection, etc. ${ }^{39}$ Second place is occupied by four weaknesses related to technology. ${ }^{40}$ Finally, population aging and the departure of young educated staff abroad is the third weakness. This process seems to affect the cantons more ${ }^{41}$ than the FB\&H and the State of Bosnia and Herzegovina. Of the seven opportunities, four have external provenance: foreign investment linked to new technologies, acceleration of the 4.0 industrial revolution, opportunities to engage in new value chains with smart specialization and the use of EU R\&D funds. ${ }^{42}$ Among the opportunities under the dominant control of domestic entities are: the development of STEM education, the acceleration of the Triple Helix process and the establishment of science and technology parks. ${ }^{43}$ Among the threats, in the first place is the outflow of personnel abroad, especially from deficient professions. Although this threat is not broken down into several elements, it is commonplace in the strategic documents of cantons. ${ }^{44}$ In the field of technology, the greatest threats are domestic or foreign investments in outdated technologies, ${ }^{45}$ which is in itself a sign of underdevelopment of the economic system. The common denominator for all weaknesses in this matrix is the marginalization of the Bosnian-Herzegovinian economy and society. The

\footnotetext{
${ }^{36}$ See Table No. 1, items 1.1. -1.4.

${ }^{37}$ Radošević, (2011): Table 3 shows four basic institutional profiles (including Kazakhstan) of relationship of financing and implementation of research in former socialist countries. Bosnia and Herzegovina is not included in the table. Based on the known data, it can be considered that Bosnia and Herzegovina belongs to the third profile: the state is the biggest financier, and universities are the largest implementers of research.

${ }^{38}$ Since only five companies responded to the questionnaire, only as an illustration we shall cite that in the period $2016-2018$ in FB\&H only one of those companies received support from public funds for their scientific-research activities (Kremić \& Trifković, 2020:36)

${ }^{39}$ See Table No. 1, items: 2.6, 2.9, $2.11-2.14$ and 2.16.

${ }^{40}$ See Table No. 1, research items: 2.1. -2.4 and 2.14

${ }^{41}$ See Table No. 1, item: 2.10

${ }^{42}$ See Table No. 1, items: 3.1., 3.2., 3.5. and 3.7.

${ }^{43}$ See Table No. 1, items: 3.4., 3.3. and 3.6.

${ }^{44}$ See Table No. 1, item: 4.1.

${ }^{45}$ See Table No. 1, items: 4.2. and 4.3.
} 
largest group of threats is in the domain of knowledge transfer from science to economy. Four elements are identified in it: weak institutional support, insufficient capacity of specialized institutions, lack of specialized capacity and insufficient level of direct science-economy cooperation. ${ }^{46}$

The second group of conclusions refers to the contradictions within the derived SWOT matrix of the innovation system. Here are the most important cases. The first case is the contradiction between determining the stable availability of scientists and qualified personnel as an element of strength, while citing the weakness reflected in the fact that technology-oriented companies are leaving $\mathrm{B} \& \mathrm{H}$ due to lack of highly qualified research staff and workforce. Identification of the outflow of the most qualified personnel as a threat to the economic development of the state points to the same contradiction. ${ }^{47}$ The second case is the mutual exclusion of allegedly good cooperation between universities and industry in the field of research and development, as an element of strength, and low level of added value in export products as a weakness of the whole system. ${ }^{48}$ In the third case, the designation of a developed organization to support entrepreneurship as a strength contradicts the claim that the insufficient number of scientific research centres and centres for acquiring skills is a weakness of our innovation system. ${ }^{49}$ Finally, the fourth case is the strength reflected in good cooperation between businesses and universities, which cannot be reconciled with the repeatedly pointed out weakness in these industry-university relations and shortcomings in the operationalization of the Triple Helix model. ${ }^{50}$ Different powers, goals and policies of the creators of strategic documents can partly explain these contradictions. ${ }^{51}$ However, taken as a whole and related to opportunities and threats, the contradictions indicate insufficient harmonization of innovation subsystems and incoherence of the innovation system in Bosnia and Herzegovina.

The elements of the innovation system identified by the SWOT analysis as the basis for strategic planning reflect only a part of the actual attitude of development decision makers towards the innovation system. For a complete picture, it is necessary to identify the most important elements of the science

\footnotetext{
${ }^{46}$ See Table No. 1, items: 4.4 and 4.6. -4.8 .

${ }^{47}$ Compare items 1.2. and 1.4 with items 2.1., 2.2. and 2.10 from Table No. 1

${ }^{48}$ Compare items 1.3. with items 2.2. and 2.7. from Table No. 1

${ }^{49}$ Compare items 1.8 with item 2.12. from Table No. 1

${ }^{50}$ Compare items 1.3. and 2.15. from Table No. 1

${ }^{51}$ State of B\&H and FB\&H entity believe that the shortcomings in the protection of intellectual property are a weakness of the development and innovation system of B\&H. Cantons don't even refer to this element (see Table No. 1, item 2.5)
} 
and technology transfer system that are not in the extrapolated innovation system SWOT matrix. The third group of conclusions from Table 1 refers to these elements. The first significant set of problems that are not even mentioned relates to the legal regulations. The effects of the Framework Law on Scientific Research at the State level, ${ }^{52}$ the consequences of the lack of a systemic law of this kind in the Federation of B\&H entity, and the failure of six cantons to enact new laws on the innovation system are not qualified as a general strategic weakness or opportunity to achieve development goals. The internal knowledge gap is clearly not in the focus of strategic development planning. Another completely neglected area are the strategies for the development of the innovation system, as one of the pillars of the knowledge society and economy. ${ }^{53}$ Their adoption is not prohibited even when the regulations are silent on this issue. Nevertheless, legislations of the state of $\mathrm{B} \& \mathrm{H}$, the RS entity and four of the cantons ${ }^{54}$ contain the obligation of the mentioned political-territorial units to adopt strategies for the development of the innovation system. Currently, instead of 14, there are only three strategies of the innovation system in different procedural status in the country, those at B\&H level, in the RS entity and in the Sarajevo Canton. The Federation and three other cantons, which have introduced an obligation to adopt a sectorial strategy into their legislation, have not done so. ${ }^{55}$ Regardless of the stated situation, the extrapolated SWOT matrix of the innovation system completely ignores the non-existence of strategies and the inaccuracy of those adopted. Third, the attitude towards the financing of the innovation system is a true test of understanding its role in fulfilling the development strategy. The development strategy of Bosnia and Herzegovina, ${ }^{56}$ research ${ }^{57}$ and theoretical works, all show that the situation in this area is completely unsatisfactory. The most important shortcomings are: absolutely unacceptable low allocations for these purposes (between $0.2 \%$ and $0.3 \%$ of GDP), the dominance of public budget (co)financing, fragmentation of already small funds, administrative

\footnotetext{
${ }^{52}$ The Framework Law on Basics of Scientific-Research Activity and Coordination of Internal and International Scientific-Research Cooperation of Bosnia and Herzegovina (see analysis of this Act in Trifković, 2020b: 95 - 102)

${ }^{53}$ Trifković, 2020b: $23-25$ and $35-37$.

${ }^{54}$ See Trifković, 2020b: 49-50

${ }^{55}$ On the legal regime of cantonal innovation system development strategies see: Trifković, 2020b: $131-134$

56 "Strategy of Development of Science in Bosnia and Herzegovina 2017-2022 - revised framework document", Council of Ministers of B\&H, 20 June 2016, p. 14-17

${ }^{57}$ Trifković, 2020b: 64, 127 and 192
} 
allocation for purposes and projects, blurred funding of science at universities, time mismatch between project activities and funds inflow, insufficient state investment in equipment, ${ }^{58}$ and the absence of customs and tax incentives. It is therefore surprising that the financing of the innovation system does not appear in any of the factors of the SWOT analysis of general development strategies. Instead, among the weakness elements of economic and financial character are those for which the political-territorial units are not directly responsible: low level of added value in export products, insufficient foreign direct investment and technology transfers, weak links between the industry and universities in the research field a small number scientific research centres and the lack of modern equipment in all areas. ${ }^{59}$ Fourth, the consequence of keeping silent about the problem of innovation system financing is the complete ignoring of fundamental and development research as instruments for resolving numerous development weaknesses and threats, including those of technological nature.$^{60}$ Accordingly, even the accelerated formation of (independent) institutes strategies do not see as an opportunity offered by the innovation system. Finally, fifth, only the West Herzegovina Canton considers that the lack of mechanisms for motivating civil servants for development affairs is a threat to the development of the innovation system and the realization of development strategies. ${ }^{61}$ Twelve other carriers of planning are avoiding this problem, thus relativizing their obligations under the public administration reform program. ${ }^{62}$

\footnotetext{
${ }^{58}$ Agency for Statistics of Bosnia and Herzegovina: "Report - Science, Technology and Digital Society: Research and Development 2019", subheading 2.1. states that of 39,728,000 BAM of gross assets invested in higher education, only 1,992,000 BAM was spent on investment costs, or $19.72 \%$. In the same year, business sector had invested 25,647,000 BAM into research and development, 9.871.000 BAM or 38.44\% in investments.

${ }^{59}$ See Table No. 1, items 2.2, 2.4, 2.7, 2.12 and 2.13. Of the 209 research projects, conducted between 2016 and 2018 by 18 institutes in the FB\&H entity, 13 of them or $6.22 \%$ were fundamental research, and 13 or $6.22 \%$ were developmental research. At the same time, 103 consulting projects were conducted, or $49.28 \%$ of the total (see: Kremić \& Trifković, 2020: 29).

${ }^{60}$ See Table No. 1, items 2.1.-2.4.

${ }^{61}$ See Table No. 1, item 2.16.

${ }^{62}$ Kremić \& Trifković, 2020:9-15 offers plenty of data that supports our claims for the territory of FB\&H. Of the 111 federal and cantonal ministries included in the research, 31 $(27.93 \%)$ hasn't responded to the questionnaire at all, $36(32.43 \%)$ stated they have no activities in the field of innovation system, and 44 (39.64\%) filled the questionnaire. According to the systematization of workplaces in FB\&H ministries, five employees deal with the issues of innovation system full time, and three more for half of worktime. In the cantonal ministries that have answered the questionnaire, the situation is however reversed. Six employees work for up to half of worktime, and only one works fulltime on the issues of the innovation
} 
All three groups of conclusions based on the extrapolated SWOT matrix of strategic planning provide reasons for a pessimistic outlook: different levels of government, each within its scope, do not include in the development SWOT analysis elements of the innovation system that require additional financing or workload. There are efforts to, at least implicitly, share the consequences of such a policy with other subjects of the system. Obviously, state bodies are treating investing in research and development as a cost, not an investment. Thus, the hypothesis of the innovation system as a stepchild of political-territorial units can be considered proven. There are two final consequences of the existing approach to the innovation system: Bosnia and Herzegovina remains in the group of countries that base their development on the efficiency of raw material exploitation while slowing down the process of creating a knowledge society and economy.

SWOT analyses of innovation system in the strategies of science development in Bosnia and Herzegovina

There are currently four documents in Bosnia and Herzegovina on the development strategy for the innovation system for the period until 2022. These are: "Strategy for the Development of Science in Bosnia and Herzegovina 2017-2022 - Revised Framework Document", version 01, dated 26 June 2016, by the Council of Ministers ${ }^{63}$ (hereinafter: SRN B\&H); "Strategy for the Development of Science in the Federation of Bosnia and Herzegovina for the Period 2011-2021 (Draft)"64 (hereinafter: SRN FB\&H), noting that the Parliament of FB\&H did not consider this document ; "Strategy of Scientific and Technological Development of Republika Srpska 2017-2021 'Knowledge for Development'" ${ }_{65}$, proposal from April 2017, the Government of the Republika Srpska (hereinafter: SNTR RS) and the "Strategy for the Development of Education and Science of Sarajevo Canton for the period

system. Of the 44 ministries that have answered the questionnaire: in 4 federal and 19 cantonal ministries there is no strategy for scientific-technological development, nor is there work on any. Only one federal ministry noted that the prime minister and the competent minister from the government on a regular monthly basis consider the state of the innovation system and higher education, etc.

${ }^{63}$ Official Gazette of B\&H, No. 22/18

${ }^{64}$ Federation of Bosnia and Herzegovina. FB\&H Ministry of Education and Science (2010)

${ }^{65}$ Republika Srpska. Government of Republika Srpska (2017) 
2018-2022 - (Draft)", Ministry of Education, Science and Youth of Sarajevo Canton, June 2017 (hereinafter: SRON KS). ${ }^{66}$

The formal-legal position of sectorial strategies of the innovation system is different. The SRN B\&H has been adopted and is valid, the SRN FB\&H is an abandoned document of unclear legal position, and the SRNT RS and SRON KS are in the draft phase. Regardless of the legal status of the documents, the data, analyses and conclusions they contain are professionally relevant, so we shall consider them. The goals and areas for which the strategies were written and their titles differ somewhat. The state level strategy views the innovation system as a whole, while the strategy of the RS pays the most attention to the technological component. Strategy of Sarajevo Canton divides attention between education and science. ${ }^{67}$ Also SWOT matrices that individual strategies contain reflect differences in the subject and titles of aforementioned documents. We give the overview in tabular form.

Table No. 2: Structure of SWOT matrix in sectoral strategies

of the innovation system in $B \& H$

\begin{tabular}{llcccc}
\hline \multirow{2}{*}{ No. } & \multirow{2}{*}{ Strategy document } & \multicolumn{5}{c}{ Number of elements in factors of the SWOT matrix } \\
\cline { 3 - 6 } & $\mathbf{2}$ & $\mathbf{S}$ & $\mathbf{W}$ & $\mathbf{0}$ & $\mathbf{T}$ \\
\hline $\mathbf{1}$ & $\mathbf{3}$ & $\mathbf{4}$ & $\mathbf{5}$ & $\mathbf{6}$ \\
\hline 1. & SRN B\&H & 7 & 24 & 14 & 11 \\
\hline 2. & SRN FB\&H & 8 & 24 & 14 & 11 \\
\hline 3. & SNTR RS & 5 & 7 & 6 & 7 \\
\hline 4. & SRON KS & $7(-3)$ & $19(-6)$ & $13(-4)$ & $8(-1)$ \\
\hline
\end{tabular}

The previous table requires some comments. First, only two elements of strength, three elements of weakness and two elements of opportunity from the SRN FB\&H matrix are not included in the national SWOT analysis. Thus, the SWOT matrices of the state and the FB\&H entity are practically identical, although they were made for different competencies and circumstances of the two political-territorial communities. Second, weaknesses dominate in all matrices. This feature is least pronounced in the RS entity. Third, SNTR RS summarized elements of each factor in the most consistent manner. And fourth, in line no. 4, which refers to the Sarajevo Canton, the numbers in

\footnotetext{
${ }^{66}$ Sarajevo Canton. Government of Sarajevo Canton. Ministry of Education, Science and Youth of Sarajevo Canton (2017). The Draft was withdrawn from the $44^{\text {th }}$ session of Sarajevo Canton Assembly on 12 October 2018

${ }^{67}$ Ibidem
} 
brackets indicate the elements of each factor that refer exclusively to the part of the educational process, without a factual impact on the innovation system. They must therefore be excluded from the analysis of the innovation system in this canton.

The science development strategy in Bosnia and Herzegovina is based on the principle of coordinated planning. It must "have a general character and represent the least common denominator of the interests involved." ${ }^{96}$ Therefore, it is not surprising that the SRN B\&H has the largest number of elements of each factor of the SWOT matrix. Their aggregation, regardless of the risks of generalization, requires the methodology of SWOT analysis and the need to compare the matrices of $\mathrm{B} \& \mathrm{H}$ and other levels of government. The results of grouping are given in tabular form. Brackets next to the numbers contain the ordinal numbers of individual elements in the matrix of $\mathrm{B} \& \mathrm{H}$.

Table No. 3: "Aggregated SWOT matrix of the Science Development Strategy of Bosnia and Herzegovina"

\begin{tabular}{clccccc}
\hline \multirow{2}{*}{ No. } & \multirow{2}{*}{ Aggregated elements } & \multicolumn{5}{c}{ SWOT matrix of the Science Development Strategy of B\&H } \\
\cline { 3 - 6 } & \multicolumn{1}{c}{$\mathbf{2}$} & $\mathbf{S}$ & $\mathbf{W}$ & $\mathbf{0}$ & $\mathbf{T}$ \\
\hline $\mathbf{1}$ & & $\mathbf{3}$ & $\mathbf{4}$ & $\mathbf{5}$ & $\mathbf{6}$ \\
\hline 1. & Higher education & $1(1,2,3)$ & $6(2,3,10,12,17,24)$ & $/$ & $/$ \\
\hline 2. & Organization and infrastructure & $8(4,8,9,16,20,21)$ & $2(2,3)$, & $/$ \\
\hline 3. & Economic-financial elements & $/$ & $4(18,19,22,23)$ & $4(1,8,10,14)$ & $3(2,3,11)$ \\
\hline 4. & Political and cultural elements & $/$ & $3(5,13,14)$ & $2(12,13)$ & $8(1,5,6,7,8,9,11)$ \\
\hline 5. & $\begin{array}{l}\text { International cooperation and foreign } \\
\text { elements }\end{array}$ & $1(4)$ & $3(1,6,15)$ & $6(4,5,6,7,9)$ & $/$ \\
\hline 6. & Other & $2(5,7)$ & $/$ & $/$ & $/$ \\
\hline
\end{tabular}

Regardless of the errors inherent in the classification of polyvalent elements, the table above provides an opportunity for a large number of questions and comments. We shall stick to the essentials. First, the element of higher education is defined inconsistently: as opposed to the three elements of strength, there are as many as six elements of weakness. At the same time, it is surprising that there are no elements related to higher education in the factors of opportunities and threats. Second, the state of the organization and infrastructure of the innovation system is accurately identified. It shows

${ }^{68}$ Trifković, 2020b:101 
the greatest number of weaknesses, as many as eight, and only two opportunities. It is notable that the funding shortcomings are clearly highlighted. Surprisingly, however, the negative consequences of the lack of funds have not been identified as threats. Third, the economic and financial shortcomings of the innovation system have been precisely identified. It is surprising that the "competitive price of scientific research work in B\&H compared to abroad" 69 is cited as an opportunity, when it is known that this is one of the main reasons for the brain drain. In addition, seven of the 14 opportunities are in some way related to international competition, although domestic entities generally have a weaker position in it. Fourth, among political and cultural elements, following key weaknesses are rightly highlighted: long-term marginalization of science, demotivating egalitarianism, and opportunism in evaluating the results of scientific research. Among the threats, three elements have economic provenance, ${ }^{70}$ and as many as seven have cultural provenance. ${ }^{71}$ Checking the accuracy of the claim about the importance of cultural threats to the innovation system in B\&H deserves special research. Fifth, elements that include international cooperation and other relations with the foreign element are most numerous in the opportunity factor. They make up six of the 14 elements, indicating distrust of domestic chances.

This entity's Law on Scientific Research and Technological Development regulates adoption of the strategy for the development of the innovation system in the Republika Srpska. ${ }^{72}$ On that basis, the current five-year strategy of scientific and technological development was adopted, also dubbed "Knowledge for Development". After considering the important challenges, "Knowledge for Development" presents six basic strategic goals, which apply equally to all subjects and all segments of the innovation system. ${ }^{73}$ In the field of science and innovation, each of them can have special manifestations. The strategy starts from the assumption that the institutional system is "a key precondition

\footnotetext{
${ }^{69}$ SWOT matrix in SRN B\&H, opportunity No. 8

${ }^{70}$ SWOT matrix in SRN B\&H states the following economic threats: 2- poor business awareness of capital owners; 3 - continuing marginalization of science at all levels; 9 - appearance of political interventions in science; 11 - expectation from the state to solve all brain waste and brain drain problems within the state and in diaspora.

${ }^{71}$ SWOT matrix in SRN B\&H, cultural threats: 1 - lack of understanding of the importance of RTD for the development of the country; 4 - reluctance to change, fear of risk and failure; 6 - lack of lifelong learning culture; 7 - lack of understanding for the consequences of brain drain; 7 - avoidance of international competition and enclosure into national framework.

72 Official Gazette of Republika Srpska 6/12, 33/14 66/18 and 84/19. For basic principles see Trifković, 2020b: $194-195$

${ }^{73}$ See ZNTR RS p. $26-42$
} 
for encouraging innovation", ${ }^{74}$ and in determining the elements of individual factors, it insists on those that are common in all segments and subjects of the innovation system. The result of this approach is a SWOT matrix. ${ }^{75}$ Its most striking methodological features are a small number of elements in each factor - a maximum of seven, and a clear content connection between the factors of strengths and opportunities, and weaknesses and threats.

For constitutional and legal-policy reasons, the FB\&H entity has not passed a new law on scientific-research activities. ${ }^{76}$ The attempt to adopt an entity strategy for the development of the innovation system has failed for the same reasons. Thus, the cantons remain the only bearers of strategic planning in this area. Their reaction to this task is uneven. ${ }^{77}$ By 2020, all cantons had passed their own laws on higher education. These laws also regulate a part of the innovation system that takes place in higher education. ${ }^{78}$ Only four cantons promulgated laws on scientific research, which regulate most of the relations of the innovation system: Sarajevo, Zenica-Doboj, Tuzla and Canton 10. These laws also regulated the adoption of a strategy for the development of scientific-research activities, i.e. the innovation system. ${ }^{79}$ Of the six cantons that have not adopted new laws on scientific research, it would be too much to expect the development of medium-term strategies for the development of the innovation system. What is surprising is the lack of strategies for the development of the innovation system in the three cantons that have regulated this matter. This makes all the more important even a partial planning of this matter in general cantonal development strategies. ${ }^{80}$

The SWOT matrix contained in the Strategy for the Development of Education and Science of the Sarajevo Canton was adopted based on Art. 46, para. 1 of the Law on Higher Education of KS. This can probably explain the fact that this strategy covers the tasks of the competent cantonal ministry, and not the totality of the innovation system in the relevant area. The consequences

\footnotetext{
$\overline{{ }^{74} \text { ZNTR RS, p. } 6}$

${ }^{75}$ ZNTR RS, p. 45

${ }^{76}$ See Trifković, 2020b: 106 - 107. Detailed situation analysis is available in Trifković, 2020a: 46 - 48

${ }^{77}$ See Trifković, 2020b: $107-108$

${ }^{78}$ See Trifković, 2020b: $169-171$

${ }^{79}$ See Trifković, 2020b:131 - 134

${ }^{80}$ Kremić \& Trifković, 2020:11 suggests that employees in ministries in FB\&H are not creators of strategy to a sufficient extent. Out of 14 employees, only two are "preparing the draft strategy". Two employees work on the preparation of foundations, five are working exclusively on administrative tasks, and five are "giving remarks and opinions".
} 
are twofold. First, significant attention has been paid to the elements of higher education that can be only indirectly significant for the entire innovation system. We will omit them in the analysis. Second, the focus of the strategy is on the science created at the university. SWOT analysis does not even mention other open issues of the innovation system, technological development in particular. Accordingly, SRON KS finds the strength elements exclusively in higher education. ${ }^{81}$ The weakness factor is the most extensive in this matrix as well. Of the 14 elements relevant to the innovation system, six of them concern personnel, ${ }^{82}$ six relate to the organization of the functioning of the system, ${ }^{83}$ and only two to the financing, and at that exclusively the financing of scientific staff and their scientific-research work. ${ }^{84}$ The first six opportunities, traditionally, are seen in international cooperation, almost exclusively in the field of teaching. Cooperation with our scientific diaspora should take place according to the same concept. ${ }^{85}$ Of the other elements of this factor, the Strategy mentions only "cooperation with the business community and the implementation of specific expert and applicative projects" ${ }^{86}$ Threats are the most contradictory factor of this matrix. First, insufficient funding for scientific research and professional development of academic staff are both a weakness and a threat. ${ }^{87}$ Furthermore, in accordance with the administrative provenance of SRON KS, the current "limited available sources of funding" 88 and "systemic uncertainty in terms of uncertain funding" 89 are only cited as future threats and not as a significant current weakness of the innovation system in Sarajevo Canton. Finally, the "inadequate image of universities and higher education institutions in the public" ${ }^{90}$ is directly opposite to the strength of image and tradition in the Sarajevo region. ${ }^{91}$ Among other elements of this factor, it is necessary to point

\footnotetext{
${ }^{81}$ SRON KS: 1 - image and tradition of higher education and scientific-research work; 2 diversity of scientific groups and 3 - accredited higher education institutions.

${ }^{82}$ SRON KS: Weaknesses, items $2-7$. It is interesting that weaknesses are identified in the lack of specific skills for writing domestic and international projects, lack of recognizability in realization of expert and applicative projects, lack of orientation and motivation, and in lack of publications in the Web of Science in relation to neighbouring countries.

${ }^{83}$ SRON KS: Weaknesses, items 1, 10,13, 15, 16 and 19.

${ }^{84}$ SRON KS: Weaknesses, items 8 and 9

${ }^{85}$ SRON KS: Opportunities, item 10

${ }^{86}$ SRON KS: Opportunities, item 9

${ }^{87}$ Compare SRON KS: Weaknesses, items 9 and 10 with Threats, items 13 and 14

${ }^{88}$ SRON KS: Threats, item 2

${ }^{89}$ SRON KS: Threats, item 1

${ }^{90}$ SRON KS: Threats, item 8

${ }^{91}$ SRON KS: Strengths, item 1
} 
out the correctly perceived threat that non-existent or non-harmonized legal regulations, strategies and policies pose to the innovation system. ${ }^{92}$

\section{SWOT Analysis of the Current State of the Innovation System in Bosnia and Herzegovina}

\section{Latest research of the innovation system in Bosnia and Herzegovina} and the manner of using their results

Six of the 13 documents of general strategic development planning and all three sectoral strategies for the development of the innovation system in $\mathrm{B} \& \mathrm{H}$, which we examined in this paper, were published in the period 20152017. This means that the data on which the elements of individual factors of the SWOT analysis are determined and the strategies are created are at least four to five years old. These facts require that the SWOT analysis of our innovation system be done based on recent research, statistics and other data. Of the new sources, we used in particular the research conducted by ANUBiH independently or with other legal and natural persons, ${ }^{93}$ new statistical reports and documents of entities that professionally deal with this area. ${ }^{94}$

Existing SWOT analyses have shown that the choice of elements of individual factors must not be based primarily on experience, ${ }^{95}$ that the SWOT matrix cannot be reduced to a list of elements of each of its four factors and that the formulations of individual elements significantly affect their position in the matrix. Such actions in reality lead to: the omission of significant elements of certain factors, essential contradictions, the appearance of the same element within different factors and - ultimately - the manipulation of this methodology.

In order to avoid these pitfalls, at least partially, we first provide a concise SWOT matrix of the innovation system in $\mathrm{B} \& \mathrm{H}$ with a minimum number of the most important elements of each factor. Such a matrix is by definition general and only relatively accurate. Therefore, it must be elaborated, i.e. supplemented by concrete elements to the extent that makes the picture of the relationships clear, and makes the SWOT matrix an operational document of

\footnotetext{
${ }^{92}$ SRON KS: Threats, items 1 and 6

${ }^{93}$ Cvitković, 2017, Trifković, 2020b, Kremić \& Trifković, 2020, Čičić; Trifković, 2020a: 39 -53;

${ }^{94}$ See part of the work on higher education as factor of strength.

${ }^{95}$ Fleisher \& Bensoussan, 2007: 91-93, state that a lot of "insightful work" is needed to answer the questions in the right way and perspective.
} 
strategic planning. We will do this by supplementing the factor of strength and its elements with the essentially related elements of other factors.

\section{A concise and elaborated SWOT matrix of the innovation system in Bosnia and Herzegovina}

The concise SWOT matrix relies on the elements of each factor that are necessary to obtain a relatively accurate macro view of the state of the innovation system in B\&H. The extremely high level of generalization of the elements of each factor allowed only their partial linking in the matrix. An element of one of the factors that has no immediate counterpart in other factors - a poor funding system and the lack of ordered ethical rules, for example - acts equally towards all other factors.

Table No. 4: Concise SWOT matrix of the innovation system in Bosnia and Herzegovina

\begin{tabular}{|c|c|c|c|}
\hline \multicolumn{4}{|c|}{ Factors } \\
\hline No. & & No. & \\
\hline 1 & 2 & 3 & 4 \\
\hline 1. & Strengths & 2. & Weaknesses \\
\hline & $\begin{array}{l}\text { Established state level framework for the } \\
\text { innovation system }\end{array}$ & 2.1. & $\begin{array}{l}\text { Based on the assumption of the competencies of lower } \\
\text { political-territorial units, a highly decentralized innovation } \\
\text { system, which also means the passivisation of state bodies } \\
\text { in this domain }\end{array}$ \\
\hline & $\begin{array}{l}\text { Same basic organizational structure of the } \\
\text { innovation system }\end{array}$ & 2.2 & $\begin{array}{l}\text { Legal gaps and different legal solutions for a number of } \\
\text { important issues of establishment and functioning of } \\
\text { innovation subsystems of lower political-territorial units }\end{array}$ \\
\hline 1.3. & Good state of the human capital & 2.3. & $\begin{array}{l}\text { Declining birth rates, decreasing number of pupils and } \\
\text { students, problems in STEM education, emigration, brain } \\
\text { drain }\end{array}$ \\
\hline 1.4. & Harmonized and stable higher education & 2.4 & $\begin{array}{l}\text { Absolutely insufficient, dominantly budget funded and } \\
\text { structurally inadequate financing of the innovation } \\
\text { system, including higher education }\end{array}$ \\
\hline 1.5. & & 2.5 & $\begin{array}{l}\text { Fragmented and incomplete ethical regulatory system in } \\
\text { the field of scientific research on technology development }\end{array}$ \\
\hline 1.6. & & 2.6. & $\begin{array}{l}\text { Partialized system of international cooperation, } \\
\text { insufficient scientific productivity and unsatisfactory } \\
\text { international ranking of domestic universities }\end{array}$ \\
\hline
\end{tabular}




\section{Opportunities}

3.1. Strengthening of the interest of state bodies, ministries in particular, in filling legal gaps, work planning, functioning and use of the innovation system

3.2. Harmonization of legislation and bylaws, and adoption of harmonized development strategies

3.3. Systematic work on connecting higher education institutions, industry and state bodies in research and development of technologies

\section{Threats}

4.1. Neglect of competencies in the field of innovation system by state bodies and inert attitude of bodies of lower political-territorial units on improvement and better functioning of the innovation system

4.2. Lack of legislation harmonization, retention of legal gaps in $F B \& H$, insufficiency of strategies and further deepening of external and internal knowledge gap

4.3. Retaining the existing inappropriate level and quality of cooperation between universities and industry along with the stagnation of the system and practice of technology transfer, especially from abroad
3.4. Adoption of a multidisciplinary strategy or program of preservation and development of human capital
4.4. Maintaining the dominance of budgetary and bureaucratic financing of research and technology development, which results in the deterioration of B\&H's global competitiveness

The previous table shows that weaknesses dominate again. The ratio of threat and opportunity factors is 11:8, which confirms the general rule of thumb in this domain. In contrast, closer examination of the strength elements shows a significant deviation from the usual state. The four elements of strength are in fact the basic conditions for the existence of any social system, and not just a good innovation system. Paradoxically, it seems that the greatest strength of our innovation system is that its existence is - possible! This attitude requires further check by elaborating the condensed matrix according to the power factor elements. We did that in Table No. 5, which is found in Annex 2. It provides a relatively comprehensive insight into the set of factors that determine the real impact of strength factors, as well as the "systemic matching" $" 96$ of the strength elements with elements of other factors.

The first two elaborated strength elements in the SWOT matrix from Table No. 5 are of political and legal nature. Their normative structure and the actual way of functioning is sufficiently known. ${ }^{97}$ The third element of

\footnotetext{
${ }^{96}$ Fleisher \& Bensoussan, 2007: 87-102

${ }^{97}$ For legal framework, see Trifković, 2020b: 95 - 106, and 168 - 188. In this paper we discussed development strategies. The answers of Bosnia and Herzegovina to the "Questionnaire of the European Commission", Chapter 25: "Science and research" contain official stance on innovation system issues. For the factors of weakness, which are related to the constitutional
} 
strength, "Good state of human capital", has a highly interdisciplinary character: demographic, ${ }^{98}$ health, educationa ${ }^{99}$ and economic. ${ }^{100}$ The resultant of action of various factors in this case gives contradictory result. The complexity of export products in the period 2010-2018 ranks Bosnia and Herzegovina between 33rd and 40th place, i.e. among "higher ranked countries", indicating developed human capital. In contrast, in the matrix there is a clearly visible trend of deteriorating condition of all factors of human capital value. ${ }^{101}$ It is very likely that negative demographic trends ${ }^{102}$ will multiply the effects of weakness factor and accelerate the conversion of certain threats into current problems. This inevitably imposes the conclusion that a comprehensive study of the state of human capital in Bosnia and Herzegovina is necessary.

The analysed SWOT matrices without exception treat higher education as a strength factor. Higher education institutions are the most important creator of codified knowledge and scientific research staff in Bosnia and Herzegovina, so the quality of their work significantly affects other elements of other factors. Through these elements, higher education essentially determines the development capacity and the dynamics of the innovation system as a whole. Therefore, we will examine this element of the strength factor in more detail.

\section{Harmonized and stable higher education}

In terms of legislation, higher education is the most regulated element of the innovation system in Bosnia and Herzegovina. ${ }^{103}$ It is fully and up-to-date

position of the state, also see Trifković, 2020a. Critique of the manner of financing of the innovation system is presented in this paper, in the part: Elements of SWOT analysis of the innovation system in strategic development documents in Bosnia and Herzegovina.

${ }^{98}$ Emirhafizović \& Zolić, 2017: 11 - 54 conclude that the $1992-1995$ war in B\&H and the social trends that followed it had "overturned all the demographic trends in the population of Bosnia and Herzegovina."

${ }^{99}$ Pašalić - Kreso, 2017:93 - 124

${ }^{100}$ Global economic indices, which use different indicators to follow the state of human capital in Bosnia and Herzegovina, are not mutually harmonized. Still, results of the nine-year development, prepared by the World Bank, are humiliating for our country. See Trifković, 2020a: $53-55$

${ }^{101}$ See also Trifković, 2020a: 54

${ }^{102}$ See Institute for Statistics of FB\&H (2020): 7, Image 1: "Comparative overview of the number of population 2019 -2070, Variant 1 and Variant 2". There is basis to assume that the situation is similar in the Republika Srpska entity.

${ }^{103}$ Trifković, 2020b: 103-106, 168-172, 213-216 
included in the EHEA through a system of international conventions and domestic legislation. Development planning is achieved through general and sectoral strategies. Regardless of the different levels of application of legal and strategic documents, the existence of planning acts has had a positive impact on social relations in this area. We will examine the real state of higher education as a key driving force of the innovation system by connecting the elements of its strength with other factors of the SWOT matrix.

The first element of the strength factor is the large number of various higher education institutions. Among them are public and private universities. Despite the uneven terminology and the different number of registered private institutions, the general picture is clear: there are eight (8) public universities and between 19 and 34 private higher education institutions. ${ }^{104}$ The data that we will present later prove that domination by number does not mean domination by quality. Secondly, predominantly thanks to public universities, all scientific and artistic fields are studied at higher education institutions in Bosnia and Herzegovina. Educational needs and the economic situation have led to the fact that today we do not have universities predominantly oriented to a particular scientific field. The fact that the Framework Law prescribes that the status of a university requires having at least five study programs in at

\footnotetext{
${ }^{104}$ According to the records of accredited higher education institutions which are kept by the Agency for Development of Higher Education and Quality Assurance of Bosnia and Herzegovina, there are eight (8) public higher education institutions and twenty-four (24) private higher education institutions in Bosnia and Herzegovina. The list of higher education institutions kept by the Centre for Information and Recognition of Documents in the Field of Higher Education of Bosnia and Herzegovina (see Bosnia and Herzegovina. Centre for Information and Recognition of Documents in the Field of Higher Education of Bosnia and Herzegovina, 2021) includes eight (8) public higher education institutions and thirty-four (34) private higher education institutions, which is a difference of ten (10) private higher education institutions compared to the previous data source. Furthermore, statistical agencies collect data on higher education related to enrolled and graduated students, as well as engaged teachers, while the number of higher education institutions is not indicated. Finally, the Institute for Statistics of the Federation of Bosnia and Herzegovina in its higher education statistics indicates the existence of ninety-two (92) higher education institutions, of which seventy (70) are public, nineteen (19) are private and three (3) are religious higher education institutions. Unlike in the previous Report (03 March 2020 for the school year 2019/2020), the Statistical Bulletin of Higher Education for 2019/2020 states the existence of sixty-seven (67) public faculties, five (5) academies, three (3) religious faculties, seven (7) colleges, and eleven (11) private universities. In its Bulletin of Higher Education, the Institute of Statistics of Republika Srpska records the existence of twenty (20) higher education institutions, of which nine (9) universities and eleven (11) higher schools, without specifying the type of institution (public / private).
} 
least three scientific fields studied at the institution also contributes to this. ${ }^{105}$ The same social reasons did not facilitate the formation of research universities, the lack of which is one of the significant weaknesses of our innovation system.

An indirect conclusion on the diversification of educational and scientific research work can be made based on the distribution of student enrolment per certain areas. The analysis of data from the Institute for Statistics of FB\&H and the Institute of Statistics of RS on the number of students enrolled in certain study programs classified in broader scientific and artistic fields shows that about $55 \%$ of all students study in the fields of social sciences, humanities and arts. About $28 \%$ of students are enrolled in STEM fields (basic sciences, technical field, electrical engineering and mathematics), $21 \%$ of students study in the field of medicine and health, while $4 \%$ of students are in the field of biotechnical sciences (agriculture, fisheries, forestry and veterinary medicine). Considering the structure of the economy and society, the dominance of social sciences is to be expected. However, these data undermine the thesis that the number of students in traditional STEM areas important for innovation and technical-technological development is unsatisfactory. The problem lies elsewhere: a large number of educated students in STEM and the medical field find jobs outside B\&H relatively easily. Due to that, the limited possibility of hiring these experts within the country and the lack of a policy to prevent the brain drain are included in the key weaknesses of the innovation system. The fact that we educate a satisfactory number of students from the STEM field does not necessarily mean that all of them will contribute to the knowledge society and economy in Bosnia and Herzegovina. Solving the problem of staff training for other countries, however, lies outside the domain of the innovation system.

Another important indicator of scientific orientation in a country is the number of published scientific papers in certain fields. For reviewing the dominant research fields of the universities in Bosnia and Herzegovina, we took information from the Scopus database, which has a somewhat wider coverage of journals and a longer time span of indexed papers compared to the Web of Science. ${ }^{106}$ The review covered seven public universities in Bosnia and Herzegovina, because the University of Bihać does not have any indexed

\footnotetext{
${ }^{105}$ Art. 10, p. 2, par. 2 of the Framework Law on Higher Education in Bosnia and Herzegovina ${ }^{106}$ Access to information is limited by a subscription contract between Clarivate Analytics and Elseviera with the University of Sarajevo as the bearer of the contract for access to databases (Scopus since 1951 to date; Web of Science since 1994 to date)
} 
works under its affiliation. The categories shown in Table No.6, "Overview of published papers in the Scopus database by branches of science and universities from 1951 to 2021" (Annex 3), reflect the taxonomy of research fields and areas according to which articles are classified in the Scopus database. Analysis of Table No.6 provides a basis for several relevant conclusions. First, in the overall structure of papers classified by research areas, medical sciences are in the forefront, followed by engineering and computer science. From the available data on published papers, it can be seen that research in the field of medical and technical sciences are dominating at universities in Bosnia and Herzegovina, while natural-mathematical and biotechnical sciences take third place. This finding coincides with the data on STEM education that we have already presented. Social sciences and humanities do not have such an intensive production, but it should be taken into account that the subject of study in these disciplines is largely socially / nationally relevant, and not necessarily internationally interesting. Finally, it is understandable that the University of Sarajevo, as our oldest and largest higher education institution, has the best results. Nevertheless, policies and strategies for the development of higher education should contain levers for gradual and scalable approximation of the performance of public universities. The most important is the gradual reform of the financing system and the raising of allocations for higher education as part of the innovation system.

Another important strength element of higher education is the principle of unity of scientific-research work and teaching. And it has several manifestations. In the first place is the equal treatment of scientific-research and teaching activities in the employment contracts of academic staff. Examples are Standards and Norms for Performing Higher Education Activities in the Sarajevo Canton. ${ }^{107}$ This bylaw primarily determines the conditions whose fulfilment is necessary for conducting activities. ${ }^{108}$ They further specify that teachers and associates are obliged to actively engage in scientific research, or artistic activities for 20 hours per week. The rest of the working week is reserved for classes, exams and administration. However, the results of the research show that the relationship between scientific and teaching work in

\footnotetext{
${ }^{107}$ Sarajevo Canton. Government of Sarajevo Canton. Ministry of Education, Science and Youth of Sarajevo Canton. Standards and Norms for Conducting the Activities of Higher Education in the Territory of Sarajevo Canton (2017)

${ }^{108}$ Standards and Norms determine the minimum staffing, spatial and other material-technical conditions necessary for conduct of higher education activities and scientific-research/artistic-research work, in accordance with the Framework Law on Higher Education in Bosnia and Herzegovina and the Cantonal Law on Higher Education
} 
practice is not yet balanced, and that teaching activities are dominant in relation to scientific work. ${ }^{109}$ This weakness is certainly a consequence of changes in curricula, which impose on the existing teaching staff a moral obligation to increase the volume of pedagogical work. The integration of science and teaching is evident from the student's engagement in scientific research. ${ }^{110}$ Another manifestation of the unity of scientific and teaching work concerns the students. Participants of the first cycle are most often involved in smaller research activities for teaching purposes, while second cycle students, as well as doctoral students, are independent researchers or members of project teams led by teachers at the level of organizational units, i.e. universities. Involving students in research increases their competencies needed for future independent research work and certainly contributes to increasing human capital in the field of science in Bosnia and Herzegovina. Finally, institutionalized forms of research work at universities are institutes. ${ }^{111}$ In the legislation of the FB\&H entity, an organizational unit of a legal person with the right to appear on the market independently has the status of an institute. The institutes of integrated universities have such a position. Their position has characteristics of a dual legal regime: the relevant law on higher education governs status issues, while titles and methods of work are governed according to the laws on scientific research. The work of university institutes has yet to be explored.

Scientists are not sufficiently numerous or represented in the workforce structure. ${ }^{12}$ Yet, most of them are concentrated in universities. ${ }^{113}$ Therefore, the third important strength element of the innovation system is a good scientific and teaching staff. At the formal level, the Framework Law on Higher Education in $\mathrm{B} \& \mathrm{H}^{114}$ and the manner of its adoption in the laws of the competent political-territorial units dictate the quality of teaching personnel through provisions on the conditions for the election of academic staff in Acomparative

\footnotetext{
${ }^{109}$ Kremić \& Trifković, 2020:21, tables 2-7

${ }^{110}$ Kremić \& Trifković, 2020:21, tables 2-8

${ }^{111}$ For legal status of institutes in Bosnia and Herzegovina see Trifković, 2020b: 45. Regulations in the FB\&H entity are presented on pp. $145-147$, and in the RS entity on pp. $203-206$. For the RS entity, see also art. 47 and 64 of the Law on Higher Education of RS.

${ }^{112}$ Trifković, 2020b: 42: In 2015 they made $0.47 \%$ in FB\&H, and $0.36 \%$ in RS of the total number of employed.

${ }^{113}$ According to the Agency for Statistics of Bosnia and Herzegovina. Science, Technology and Digital Society, Statistics Research and Development 2019, of 2.883 employees in research and development in 2019, 2.271 of them worked in higher education. Of that number 1.871 were researches, while technical and other staff made up 400 . Worrying fact is that more than half of researchers (970) were engaged for less than full time working hours.

${ }^{114}$ See articles $28-35$
} 
review of internal legislation shows that there are no major deviations from the framework provisions. This fact is, on the one hand, a reflection of the objectively unsatisfactory conditions in which universities operate, and on the other hand, it may indicate an underdeveloped autonomy of universities that leads to settling with minimum standards. The direct synthetic expression of the action of all factors of the elaborated SWOT matrix at the institutional level can also be the global evaluation of the universities of Bosnia and Herzegovina. Currently we have to present it according to the Webometrics ranking, ${ }^{115}$ stating only the general ranking: 1 . UNSA $-1675 ; 2$. UNBL 2658; 4. UNTZ - 3694; 5. IUS - 3786; 7. SVM - 4748; 8. UNZE - 5129, etc. It is notable that among the top 10 universities in Bosnia and Herzegovina are four private universities; 3. International University of Sarajevo - 3557; 6. IU Burch - 3979; 9. European University Brcko - 6109 and 10. SSST - 6166.

From all that was presented so far, it is evident that higher education in Bosnia and Herzegovina as a system - taking into account the effects of objectively conditioned weaknesses and great individual and institutional achievements - has only just begun to work systematically on acceptance of the criterion of excellence. That is why we must pay special attention to this opportunity of our innovation system. Bringing scientific-research institutions closer to the European Research Area implies the development of excellence in research, ie the recognition of the institution as a centre of excellence in research. One of the mechanisms established at European level is the awarding of the prize or logo "Excellence in Research". ${ }^{116}$ The European Commission awards this logo as a public recognition to research institutions that develop processes for harmonizing the employment and career development policies of researchers with the Charter and the Code for Research Institutions. ${ }^{117}$ Institutions that are eligible to use this logo show a commitment to implementing a fair and transparent process of recruiting and promoting researchers. In order for the institution to receive this logo, which is evaluated in regular cycles through internal and external processes, it is necessary to develop a Human Resources Strategy for Researchers (HRS4R) with an Action Plan, and the highest academic bodies must adopt these two documents. At present, only three universities in Bosnia and Herzegovina have the right to carry the "Excellence in Research" logo. These are the University of Banja Luka since April 2015, the University of East Sarajevo since 2017 and the University of

\footnotetext{
${ }^{115}$ Consejo Superior de Investigaciones Científicas (2021)

${ }^{116}$ European Commission (2021)

${ }^{117}$ European Commission (2019)
} 
Sarajevo since 2019. For comparison, in the Republic of Croatia six universities and eight scientific institutes have this logo, while in Serbia four universities have qualified for this award. At first glance it may seem that this logo is not directly related to excellent research projects. However, insight into the elements of the Charter and the Code makes it clear that the European Commission links research excellence to engagement of outstanding scientists, creating an environment in which they can work freely and socially responsibly, and pool their efforts to create change based on quality research.

\section{Conclusions}

1. SWOT analysis is widely accepted in Bosnia and Herzegovina as an instrument of general and sectoral strategic planning, including the development of the innovation system. Its application in the FB\&H entity has become legally binding. It is likely to gain the same status in the RS entity soon. These facts require intensive consideration of the methodological issues of SWOT analysis.

2. The innovation system in Bosnia and Herzegovina operates in an unfavourable internal social, economic, political and legal environment. Allocations for research and development are essentially considered a cost, not an investment. Therefore, the treatment of research and development in SWOT analyses prepared for general strategic documents does not correspond to the potentials of the innovation system to achieve development goals.

3. Adoption of strategies for the development of the innovation system is neglected in Bosnia and Herzegovina. Only the state of Bosnia and Herzegovina, the entity of Republika Srpska and the Canton of Sarajevo have valid strategies and SWOT analyses in this area. Such situation is a reliable indicator of the unsatisfactory attitude of politics towards the innovation system, a factor of deepening the internal knowledge gap and a sign of the deteriorating position of Bosnia and Herzegovina in international competition.

4. The comparison of our SWOT analysis of the innovation system, based on recent research, with the SWOT matrices from the documents of general and sectoral strategic planning shows a significant correlation between them. Differences exist particularly in the choice of individual elements of each factor, the treatment of financing as a weakness of the system, the presence of technological development and the impact 
of international cooperation on improving the state of the innovation system.

5. In all SWOT matrices, the relatively good state of higher education and human capital are the most important strengths of the innovation system. Such unison does not exist in other factors.

6. All conducted SWOT matrices are proof that the existing innovation system in Bosnia and Herzegovina is neither sufficiently developed nor sufficiently connected in terms of interests, targets, norms and function to the extent that it would make it a decisive factor in moving towards a knowledge society and economy. Therefore, our innovation system does not allow the national economy to move from the phase of more efficient use of raw materials to the phase of production of knowledgebased goods.

7. SWOT analysis of the innovation system in Bosnia and Herzegovina shows that it is a factor of exceptionally slow and in various ways limited social and economic progress, which in global competition objectively means stagnation, or relative regression in development. 


\section{Annex 1}

Table No. 1: SWOT matrix of the innovation system extrapolated from development documents in Bosnia and Herzegovina

\begin{tabular}{|c|c|c|c|}
\hline No. & $\begin{array}{l}\text { Factors of SWOT } \\
\text { analysis }\end{array}$ & $\begin{array}{l}\text { Elements of individual factors } \\
\text { of the SWOT analysis }\end{array}$ & $\begin{array}{l}\text { Abbreviated titles of } \\
\text { documents and pages }\end{array}$ \\
\hline 1 & 2 & 3 & 4 \\
\hline 1, & STRENGTHS & & \\
\hline 1.1. & & $\begin{array}{l}\text { High quality education in the field of mathematics and } \\
\text { natural sciences }\end{array}$ & SO for BiH, 31 \\
\hline 1.2. & & $\begin{array}{l}\text { Stable availability of scientists and engineers, quality } \\
\text { university teaching staff }\end{array}$ & $\begin{array}{l}\text { SO for BiH, 31; } \\
\text { SR SBK, } 31\end{array}$ \\
\hline 1.3. & & $\begin{array}{l}\text { Cooperation between universities and industry in the } \\
\text { field of research and development }\end{array}$ & $\begin{array}{l}\text { SO for BiH, 31; } \\
\text { SR ZDK, } 236\end{array}$ \\
\hline 1.4. & & $\begin{array}{l}\text { Qualified professional staff in various economic and } \\
\text { social fields }\end{array}$ & $\begin{array}{l}\text { NSP TK, 226; } \\
\text { SR SBK, 30; } \\
\text { SR ZDK, 238; } \\
\text { SR BPK, } 44\end{array}$ \\
\hline 1.5. & & Wide use of internet & SO for BiH, 31 \\
\hline 1.6. & & Dynamic and competitive IT sector & SR FBiH, 151 \\
\hline 1.7. & & Accredited and developed higher education system & $\begin{array}{l}\text { SR ŽP, 49; } \\
\text { ISR USK, 111; } \\
\text { SR SBK,31; } \\
\text { SR ZDK, 236; } \\
\text { SR KS 296; } \\
\text { SR HNŽ, } 113\end{array}$ \\
\hline 1.8. & & Developed organizations to support entrepreneurship & $\begin{array}{l}\text { SR ZDK, 236; } \\
\text { SR ŽZH } 56\end{array}$ \\
\hline 1.9. & & Legal framework for action in scientific research & SR KS, 297 \\
\hline 1.10 & & Registered geographical indications & SR ŽZH 56 \\
\hline 2. & WEAKNESSES & & \\
\hline 2.1. & & $\begin{array}{l}\text { Technology-oriented companies are leaving B\&H } \\
\text { due to a lack of highly qualified labour and research } \\
\text { workforce }\end{array}$ & SR BiH, 7 \\
\hline 2.2. & & $\begin{array}{l}\text { Low level of added value in export products; } \\
\text { underdeveloped creative industry }\end{array}$ & $\begin{array}{l}\text { SO for BiH, 31; } \\
\text { SR ZDK, 236; } \\
\text { K 10, } 31\end{array}$ \\
\hline 2.3. & & $\begin{array}{l}\text { Low level of technology, marketing, research and } \\
\text { development in enterprises, especially those for green } \\
\text { growth and small and medium enterprises }\end{array}$ & $\begin{array}{l}\text { SO for BiH, 31; } \\
\text { SR ŽP, 49; } \\
\text { SR HNŽ, } 113\end{array}$ \\
\hline
\end{tabular}




\begin{tabular}{|c|c|c|c|}
\hline No. & $\begin{array}{l}\text { Factors of SWOT } \\
\text { analysis }\end{array}$ & $\begin{array}{l}\text { Elements of individual factors } \\
\text { of the SWOT analysis }\end{array}$ & $\begin{array}{l}\text { Abbreviated titles of } \\
\text { documents and pages }\end{array}$ \\
\hline 1 & 2 & 3 & 4 \\
\hline 2.4. & & $\begin{array}{l}\text { Insufficient level of incoming FDI and technology } \\
\text { transfers }\end{array}$ & SO for BiH, 31 \\
\hline 2.5 & & Shortcomings in the protection of intellectual property & $\begin{array}{l}\text { SO for BiH, 31; } \\
\text { SR FBiH, 152; }\end{array}$ \\
\hline 2.6 & & $\begin{array}{l}\text { Lack of a strategic framework for the development of } \\
\text { digital economy }\end{array}$ & $\begin{array}{l}\text { SR FBiH ,151; } \\
\text { SR ŽP, } 49\end{array}$ \\
\hline 2.7. & & $\begin{array}{l}\text { Insufficient involvement of businesses in research and } \\
\text { development activities of the universities }\end{array}$ & $\begin{array}{l}\text { SR FBiH, 152; } \\
\text { SR HNŽ, 111; } \\
\text { SR ŽZH } 57\end{array}$ \\
\hline 2.8. & & $\begin{array}{l}\text { Lack of legal and strategic framework and poor } \\
\text { coordination of the innovation system; insufficient } \\
\text { coordination in development management; } \\
\text { inconsistent application of the law on scientific } \\
\text { research }\end{array}$ & $\begin{array}{l}\text { SR FBiH, } 152 \\
\text { ISR USK, 111; } \\
\text { SR ZDK, 239; } \\
\text { SR HNŽ, } 111\end{array}$ \\
\hline 2.9. & & Tax policy that isn't encouraging development & SR FBiH, 152 \\
\hline 2.10 & & $\begin{array}{l}\text { Reduced natural population growth and migration } \\
\text { abroad, especially of young people }\end{array}$ & $\begin{array}{l}\text { SR ŽP, } 49 ; \\
\text { SR ZDK, 236; } \\
\text { SR ZDK, 241; } \\
\text { SR KS, 300; } \\
\text { K 10, } 32\end{array}$ \\
\hline 2.11. & & $\begin{array}{l}\text { Insufficient investment in campus and educational } \\
\text { infrastructure }\end{array}$ & NSP TK, 226 \\
\hline 2.12 & & $\begin{array}{l}\text { Insufficient number of scientific-research centres and } \\
\text { centres for acquiring practical skills }\end{array}$ & NSP TK, 226 \\
\hline 2.13. & & Lack of modern equipment in all areas & $\begin{array}{l}\text { NSP TK, 226-227; SR } \\
\text { ZDK, } 238\end{array}$ \\
\hline 2.14 & & $\begin{array}{l}\text { Insufficient promotion and encouragement of } \\
\text { innovation, research and development }\end{array}$ & SR HNŽ, 110 \\
\hline 2.15 & & $\begin{array}{l}\text { Weak links between the public, private and higher } \\
\text { education sectors }\end{array}$ & $\begin{array}{l}\text { SR HNŽ, 110; } \\
\text { SR ŽZH } 57\end{array}$ \\
\hline 2.16 & & $\begin{array}{l}\text { Lack of a mechanism for motivating civil servants for } \\
\text { development work }\end{array}$ & SR ŽZH 57 \\
\hline 3. & OPPORTUNITIES & & \\
\hline 3.1. & & Foreign direct investments (in modern technologies) & SR BiH, 9; \\
\hline 3.2. & & $\begin{array}{l}\text { The momentum of the fourth industrial revolution and } \\
\text { genetics; Use of technologies that do not harm the } \\
\text { environment }\end{array}$ & $\begin{array}{l}\text { SR FBiH, } 154 \\
\text { SR SBK, } 32\end{array}$ \\
\hline
\end{tabular}




\begin{tabular}{|c|c|c|c|}
\hline No. & $\begin{array}{c}\text { Factors of SWOT } \\
\text { analysis }\end{array}$ & $\begin{array}{c}\text { Elements of individual factors } \\
\text { of the SWOT analysis }\end{array}$ & $\begin{array}{l}\text { Abbreviated titles of } \\
\text { documents and pages }\end{array}$ \\
\hline 1 & 2 & 3 & 4 \\
\hline 3.3. & & $\begin{array}{l}\text { Cooperation between the industry, academia and } \\
\text { government in research (the triple helix) and smart } \\
\text { specialization }\end{array}$ & $\begin{array}{l}\text { SR FBiH, 155; } \\
\text { SR KS, } 300\end{array}$ \\
\hline 3.4 . & & Development of STEM education & SR FBiH, 155 \\
\hline 3.5 . & & $\begin{array}{l}\text { Global value chains and the possibility of smart } \\
\text { specialization }\end{array}$ & SR ŽP, 51 \\
\hline 3.6. & & Development of science-technology parks & NSP TK, 226 \\
\hline 3.7. & & Use of EU funds for $S \& R$ and $R \& D$ work & SR KS, 299 \\
\hline 4. & THREATS & & \\
\hline 4.1. & & $\begin{array}{l}\text { Outflow of personnel (departure of the educated and } \\
\text { youth) especially in globally deficient professions, e.g. } \\
\text { medical }\end{array}$ & $\begin{array}{l}\text { SR BiH,8 } \\
\text { ISR USK, 112; } \\
\text { NSP TK, 226 i 228; } \\
\text { SR HNŽ, 111; } \\
\text { SR BPK 45 }\end{array}$ \\
\hline 4.2 . & & $\begin{array}{l}\text { The threat of marginalization of B\&H economy, science } \\
\text { and society; investing in outdated technologies }\end{array}$ & $\begin{array}{l}\text { SO za BiH, 32; } \\
\text { SR ZDK, 242-243 }\end{array}$ \\
\hline 4.3. & & $\begin{array}{l}\text { Failure to attract foreign direct investment and } \\
\text { technology transfer }\end{array}$ & SO za BiH, 32 \\
\hline 4.4. & & $\begin{array}{l}\text { Lack of transfer of new knowledge and professional } \\
\text { assistance from scientific institutions, especially in } \\
\text { agriculture and adaptation to climate change }\end{array}$ & SR ŽP, 51 \\
\hline 4.5 . & & Disincentive tax and customs policy & ISR USK, 112 \\
\hline 4.6. & & Insufficient capacities of $S \& R$ and R\&D centres & SR SBK, 32 \\
\hline 4.7. & & Weak institutional support to S\&R activities & SR ZDK, 240 \\
\hline 4.8. & & $\begin{array}{l}\text { Low level of cooperation of R\&l institutions and } \\
\text { industry }\end{array}$ & SR ZDK, 240 \\
\hline
\end{tabular}

Legend:

1. SR for BiH - "Strategija razvoja Bosne i Hercegovine, Radni document", Council of Ministers, $2010^{118}$

2. SO for BiH - "Strateški okvir za Bosnu i Hercegovinu", Council of Ministers, 2015. ${ }^{119}$

3. SR FBiH - "Strategija razvoja Federacije Bosne i Hercegovine", FBiH Government, $2020^{120}$

\footnotetext{
${ }^{118}$ Bosnia and Herzegovina. Council of Ministers (2010)

${ }^{119}$ Bosnia and Herzegovina. Council of Ministers (2015)

${ }^{120}$ Federation of Bosnia and Herzegovina. Government of the Federation of Bosnia and Herzegovina (2020)
} 
4. SR ŽP - "Strategija razvoja Županije Posavske 2021 -2027”, Posavina Canton, $20211^{121}$

5. ISR USK - "Integrirana strategija razvoja Unsko-Sanskog kantona”, USK Government, $2014^{122}$

6. NSP TK - "Nacrt strateške platforme razvoja Tuzlanskog kantona", TK Government, $2015^{123}$

7. SR SBK - “Strategija razvoja Srednjobosanskog kantona za period 2016 - 2020”, 2016

8. SR ZDK - "Strategija razvoja Zeničko-dobojskog kantona za period 2021 - 2027, Nacrt", ZDK Canton, $2020^{125}$

9. SR KS - "Strategija razvoja Kantona Sarajevo, Nacrt - proširena verzija". KS - Development Planning Institute, $2020^{126}$

10. SR HNŽ - “Strategija razvitka Hercegovačko-neretvanske županije za period 2021. 2027. - Nacrt strateške platforme", HNŽ Government, $2020^{127}$

11. SR BPK - "Strategija razvoja Bosansko-podrinjskog kantona Goražde za period 2016.2020. Godine", $2015^{128}$

12. SR ŽZH - "Strategija razvoja Županije Zapadnohercegovačke 2021 - 2027", ŽZH, $2020^{129}$

13. K 10 - "Strategija razvoja kantona 10 za period 2016 - 2020. godina, Nacrt", 2015

\footnotetext{
${ }^{121}$ Federation of Bosnia and Herzegovina. Posavina Canton (2021)

${ }^{122}$ Federation of Bosnia and Herzegovina. Una-Sana Canton (2014)

${ }^{123}$ Federation of Bosnia and Herzegovina. Tuzla Canton (2015)

${ }^{124}$ Federation of Bosnia and Herzegovina. Central Bosnia Canton (2016)

${ }^{125}$ Federation of Bosnia and Herzegovina. Zenica-Doboj Canton (2020)

${ }^{126}$ Federation of Bosnia and Herzegovina. Sarajevo Canton (2020)

${ }^{127}$ Federation of Bosnia and Herzegovina. Herzegovina-Neretva Canton (2020)

${ }^{128}$ Federation of Bosnia and Herzegovina. Bosnian-Podrinje Canton Goražde (2015)

${ }^{129}$ Federation of Bosnia and Herzegovina. West Herzegovina Canton (2021)

${ }^{130}$ Federation of Bosnia and Herzegovina. Canton 10 (2015)
} 


\section{Annex 2}

Table No. 5: SWOT matrix of the innovation system in Bosnia and Herzegovina elaborated per elements of strength factor

\section{Established state framework for the innovation system}

\begin{tabular}{|c|c|c|c|}
\hline No. & & No. & \\
\hline 1 & 2 & 3 & 4 \\
\hline 1. & Strengths & 2. & Weaknesses \\
\hline 1.1. & $\begin{array}{l}\text { The Framework Law on the Fundamentals } \\
\text { of Scientific Research and Coordination of } \\
\text { Internal and International Scientific Research } \\
\text { Cooperation was adopted (Official Gazette of } \\
\text { B\&H / 09). }\end{array}$ & 2.1. & $\begin{array}{l}\text { The state of B\&H is responsible for the international } \\
\text { relations of the innovation system, but it does not } \\
\text { have effective constitutional and legal instruments } \\
\text { for fulfilling the agreed obligations and rights within } \\
\text { the country. }\end{array}$ \\
\hline 1.2. & $\begin{array}{l}\text { The Stabilization and Association Agreement } \\
\text { opens up opportunities for ERA accession }\end{array}$ & 2.2 & $\begin{array}{l}\text { Assumption of competencies of lower political- } \\
\text { territorial units for all } \\
\text { affairs that are not explicitly assigned by the } \\
\text { constitution to a higher political-territorial unit }\end{array}$ \\
\hline 1.3. & $\begin{array}{l}\text { Adopted state strategy for development of S\&R } \\
\text { activities }\end{array}$ & 2.3. & $\begin{array}{l}\text { Omission of general and fragmentation of special } \\
\text { interest for the innovation system according to the } \\
\text { territorial competence for passing laws in this area }\end{array}$ \\
\hline 1.4. & $\begin{array}{l}\text { Adopted Framework Law on Higher Education } \\
\text { in B\&H (50/07 and 59/09) }\end{array}$ & 2.4 & $\begin{array}{l}\text { In terms of amounts and structure, absolutely } \\
\text { insufficient and inadequate budget financing of the } \\
\text { functioning of the innovation system, accompanied } \\
\text { by the lack of incentives and benefits for research and } \\
\text { development }\end{array}$ \\
\hline
\end{tabular}

1.5. Interdependence of scientific and teaching work 2.5. / at universities has been established

1.6. Ongoing finalization of a harmonized strategic 2.6. / planning system in B\&H

\section{Opportunities 4. Threats}

3.1. Completion of legal regulation of the science system by enacting new laws in six cantons that did not do so after the signing of the Dayton Peace Agreement

3.2. Adoption of 11 missing strategies for the development of the innovation system (nine cantons, FB\&H, Brčko District)
4.1. Legal possibility of lower political-territorial units not to use their competencies and thus reduce the effects of the state's efforts in international scientific and technical cooperation

4.2. Autarchic application of the principles of decentralized and polycentric planning of innovation system development 
3.3. Developing mechanisms for connecting the Ministry of Civil Affairs of B\&H and the subjects of the innovation system in creating and fulfilling forms of international cooperation

3.4. Strengthening international exchange and circulation of scientific-research staff
4.3. Constitutional-legal and political difficulties in the activities of the FB\&H on the harmonization of legal and strategic regulations of the innovation system

4.4. Deepening of the internal gap in knowledge for objective reasons (e.g. different degree of development of the cantons), political attitudes and cultural situation (e.g. attitude towards the knowledge society and economy)

\section{Harmonized structure of the innovation system}

No. No.

\begin{tabular}{cccc}
\hline & Strengths & & Weaknesses \\
\hline 1 & 2 & 3 & 4 \\
\hline
\end{tabular}

1.1. Uniform systematization of jobs in the innovation system. Institute and university titles are equal, and the conditions for election are very similar

1.2. Higher education is part of the EHEA and functions in a uniform manner

1.3. There are seven types of subjects of the innovation system of a largely uniform status regime

1.4. Specific legal solutions on the innovation system within political-territorial units can be harmonized without compromising the unity of any subsystem

1.5. /

\section{6. /}

1.7. /

1.8. /
3.1. Insufficient participation of scientists and researchers in the total population and in the labour force

3.2. There are small differences in the conditions for the selection of teachers, researchers and scientific associates, but they have a significant effect on staff mobility within the innovation system in the country

3.3. From the point of view of optimal functioning of the innovation system, each of the seven types of subjects has its specific status-legal weaknesses

3.4. Insufficient productivity of the scientific staff

3.5. The innovation system is not a policy priority in legislative, planning, strategic and financial terms

3.6. Absolutely insufficient allocations for science and completely inadequate system of financing

3.7. There is no systematic approach to scientific ethics as a control mechanism of a social nature and a condition for the approval of individual projects

3.8. The lack of interest of the state administration in the functioning, and for participation in the work of the innovation system

\section{Opportunities \\ 4. Threats}
2.1. Adopt the lacking and harmonize existing laws on the innovation system
4.1. Legal possibility of lower political-territorial units not to improve and harmonize the legislation of the innovation system in their area


2.2. Adopt non-existent and harmonize valid bylaws on the innovation system

Increasing the amount and improving the

2.3. methodology and budget financing, improving the structure of financing per subjects and sources

2.4. Alignment of foreign direct investment policy with the strategy and policy of the innovation system
4.2. The contrast between the existence of state competence for international relations of the innovation system and the lack of powers and instruments for the implementation of international arrangements within the state

4.3. The FB\&H has the authority to legally regulate industry and economic relations, but not to regulate the innovation system

4.4. The absence of large economic organizations that would be the bearers of the development of the innovation system in the economy, but also in the state

\section{Good state of human capital}

\begin{tabular}{cccc}
\hline No. & & No. & \\
\hline 1 & 2 & 3 & 4 \\
\hline 1. & Strengths & 2. & Weaknesses \\
\hline 1.1. & Good healthcare system & 2.1. & $\begin{array}{l}\text { Insufficient investment, primarily by the state, in all } \\
\text { components of human capital, and especially in public } \\
\text { health }\end{array}$ \\
\hline
\end{tabular}

1.2. Education system in line with European standards
2.2. The existence of an inner gap in knowledge. Human capital in all parts of the country is not equally developed nor does it have the same development conditions

2.3. Insufficient concentration of own human capital in independent institutes and economic entities
1.3. Still good state of human capital, which is manifested by the objective ability of the BosnianHerzegovinian economy to place complex export products on the international market

1.4. Researchers with the title of Doctor of Science are dominant in numbers in the innovation system

\section{Opportunities}

3.1. Increasing the coverage of age and professional groups of employees with the appropriate type of lifelong learning

3.2. Increasing domestic demand for institutional knowledge and services

3.3. Reintegrate STEM education into state education policy

3.4. Strengthening the parts of the public health system relevant to the maintenance and development of human capital

\section{Threats}

4.1. Further devaluation of knowledge, skills and competencies in the social system, especially in the policy sub-system

4.2. Insufficiently fast growth of information and communication skills and computer literacy of the population

4.3. Declining birth rates, population aging and emigration

4.4. Brain drain 
2.5. Eliminate differences between the declaratory

4.5. / and the actual attitude towards human capital through planned actions

\section{Harmonized and stabilized higher education}

\begin{tabular}{|c|c|c|c|}
\hline No. & & No. & \\
\hline 1 & 2 & 3 & 4 \\
\hline 1. & Strengths & 2. & Weaknesses \\
\hline 1.1. & $\begin{array}{l}\text { The most important conventions defining the } \\
\text { EHEA have been signed and implemented }\end{array}$ & 2.1. & $\begin{array}{l}\text { Universities are mostly oriented towards teaching. } \\
\text { There are no research universities }\end{array}$ \\
\hline 1.2. & $\begin{array}{l}\text { The Framework Law on Higher Education in } \\
\text { B\&H was adopted and implemented (Official } \\
\text { Gazette of B\&H 59/07 and 59/09). The RS entity } \\
\text { and all cantons in the FB\&H entity have adopted } \\
\text { their own laws in this area }\end{array}$ & 2.2 & $\begin{array}{l}\text { A small number of centres of excellence even in the } \\
\text { political-territorial units in which they are legally } \\
\text { regulated }\end{array}$ \\
\hline 1.3. & Favourable university structure & 2.3. & Very limited cooperation with the industry \\
\hline 1.4. & $\begin{array}{l}\text { The unity of science and teaching set as a } \\
\text { principle and largely realized in practice }\end{array}$ & 2.4 & $\begin{array}{l}\text { Unsatisfactory placement of all domestic } \\
\text { universities on international rankings }\end{array}$ \\
\hline 1.5. & All scientific and artistic fields are studied & 2.5 . & Insufficient capacities for technology transfer \\
\hline 1.6. & Relatively good scientific-teaching staff & 2.6 & $\begin{array}{l}\text { Limited ability to hire the best staff from the } \\
\text { industry and among graduate students }\end{array}$ \\
\hline
\end{tabular}

1.7. Existence of institutes as research units, mostly 2.7. An undefined policy of counteracting the brain drain at public universities.

\section{Opportunities}

3.1. Accelerated employment of professionals in deficit professions, especially younger ones

3.2. Establish policy and provide funds for systematic international cooperation and staff circulation

\section{Threats}

4.1. Slow development of autonomy of higher education institutions

4.2. Maintaining the current revenue structure of higher education institutions. For the public institutions, that means further dominance of the budget funding, and for the private ones - tuition fees. The stagnation of $R \& D$ income is dangerous for both universities and society

3.3. Adopt strategy and operational documents for the establishment of centres of excellence

4.3. Tendencies of university self-isolation and provincialization

3.4. Planned approach to measures to increase publication in journals that are followed by indexing databases and to improve the rank of our universities, especially public ones

3.5. Adopt the general strategy and strategies of higher education institutions for cooperation with business entities
4.4. Maintaining the current level of investment in equipment and research projects and persisting in the system of insufficient co-financing of procurement and research

4.5. Maintaining the current level of investment in equipment and research projects and persisting in the system of insufficient co-financing of procurement and research 


\section{Annex 3}

Table No.6: "Overview of published papers in the Scopus database per branches of science and universities"

\begin{tabular}{|c|c|c|c|c|c|c|c|c|c|c|}
\hline \multirow[t]{2}{*}{ FIELD } & \multicolumn{8}{|c|}{ UNIVERSITIES } & \multirow{2}{*}{$\frac{\text { SUM }}{\Sigma}$} & \multirow{2}{*}{$\begin{array}{c}\% \\
\text { PAPERS }\end{array}$} \\
\hline & UNSA & UNBL & UNTZ & SVEM & UIS & UNZE & UNMO & UNBI & & \\
\hline Medicine & 2085 & 353 & 461 & 375 & 178 & 72 & 17 & 0 & 3541 & $19.9 \%$ \\
\hline Engineering & 1264 & 494 & 341 & 116 & 202 & 101 & 63 & 0 & 2581 & $14.5 \%$ \\
\hline Computer sciences & 963 & 307 & 213 & 81 & 157 & 43 & 74 & 0 & 1838 & $10.3 \%$ \\
\hline $\begin{array}{l}\text { Agriculture and biology } \\
\text { sciences }\end{array}$ & 471 & 347 & 65 & 101 & 101 & 0 & 17 & 0 & 1102 & $6.2 \%$ \\
\hline Social sciences & 458 & 135 & 149 & 136 & 78 & 25 & 23 & 0 & 1004 & $5.6 \%$ \\
\hline Mathematics & 461 & 200 & 70 & 37 & 82 & 27 & 10 & 0 & 887 & $5.0 \%$ \\
\hline Physics and astronomy & 442 & 184 & 75 & 24 & 82 & 39 & 2 & 0 & 848 & $4.8 \%$ \\
\hline $\begin{array}{l}\text { Biochemistry, genetics } \\
\text { and molecular biology }\end{array}$ & 360 & 166 & 66 & 85 & 52 & & 1 & 0 & 730 & $4.1 \%$ \\
\hline Environmental science & 273 & 147 & 90 & 38 & 58 & 11 & 7 & 0 & 624 & $3.5 \%$ \\
\hline Chemistry & 188 & 120 & 58 & 41 & 96 & 17 & 2 & 0 & 522 & $2.9 \%$ \\
\hline Science on materials & 130 & 174 & 40 & 31 & 75 & 54 & 8 & 0 & 512 & $2.9 \%$ \\
\hline Chemical engineering & 231 & 77 & 62 & 27 & 71 & 20 & 2 & 0 & 490 & $2.8 \%$ \\
\hline Energy & 194 & 96 & 84 & 10 & 79 & & 5 & 0 & 468 & $2.6 \%$ \\
\hline Art and humanities & 170 & 50 & 62 & 81 & 12 & 22 & 10 & 0 & 407 & $2.3 \%$ \\
\hline $\begin{array}{l}\text { Business, management } \\
\text { and accounting }\end{array}$ & 173 & 57 & 25 & 25 & 23 & 9 & 9 & 0 & 321 & $1.8 \%$ \\
\hline $\begin{array}{l}\text { Pharmacology, toxicology } \\
\text { and pharmaceutics }\end{array}$ & 145 & 70 & 12 & 17 & 11 & 1 & 0 & 0 & 256 & $1.4 \%$ \\
\hline $\begin{array}{l}\text { Science on Earth and } \\
\text { planets }\end{array}$ & 83 & 62 & 55 & 22 & 19 & 3 & 1 & 0 & 245 & $1.4 \%$ \\
\hline Health studies & 88 & 25 & 42 & 41 & 43 & 2 & 3 & 0 & 244 & $1.4 \%$ \\
\hline $\begin{array}{l}\text { Decision making } \\
\text { (interdisciplinary field) }\end{array}$ & 106 & 35 & 11 & 4 & 30 & 8 & 9 & 0 & 203 & $1.1 \%$ \\
\hline $\begin{array}{l}\text { Economy, econometrics } \\
\text { and finances }\end{array}$ & 111 & 35 & 17 & 12 & 18 & & 5 & 0 & 198 & $1.1 \%$ \\
\hline Physiology & 79 & 39 & 30 & 22 & 7 & 2 & 0 & 0 & 179 & $1.0 \%$ \\
\hline Veterinary science & 105 & 25 & 4 & 16 & 5 & 1 & 1 & 0 & 157 & $0.9 \%$ \\
\hline $\begin{array}{l}\text { Immunology and } \\
\text { Microbiology }\end{array}$ & 79 & 12 & 11 & 18 & 7 & 0 & 0 & 0 & 127 & $0.7 \%$ \\
\hline Neuroscience & 52 & 13 & 18 & 5 & 3 & 0 & 0 & 0 & 91 & $0.5 \%$ \\
\hline
\end{tabular}


Special Editions ANUBiH CC, ODN Volume 18, pp. 403-446

\begin{tabular}{lcccccccccc}
\hline Nursing science & 50 & 8 & 15 & 6 & 4 & 3 & 1 & 0 & 87 & $0.5 \%$ \\
\hline Dentistry & 43 & 11 & & 9 & 20 & 1 & 0 & 0 & 84 & $0.5 \%$ \\
\hline Multidisciplinary fields & 36 & 15 & 6 & 4 & 7 & 0 & 2 & 0 & 70 & $0.4 \%$ \\
\hline & 8840 & 3257 & 2082 & 1384 & 1520 & 461 & 272 & 0 & 17810 & \\
\hline \% PER UNIVERSITY & $49.6 \%$ & $18.3 \%$ & $11.7 \%$ & $7.8 \%$ & $8.5 \%$ & $2.6 \%$ & $1.5 \%$ & & & \\
\hline
\end{tabular}

\section{Thanks}

Authors wish to thank dipl. comp. and dipl. bibl. Saša Madacki for the great help in obtaining and synthesis of data related to the number of higher education institutions in Bosnia and Herzegovina and the structure of scientificresearch papers in the SCOPUS database.

\section{Literature}

Agency for Development of Higher Education and Quality Assurance of Bosnia and Herzegovina. List of accredited higher education institutions in B\&H. Taken from http://hea. gov.ba/akreditacija_vsu/Default.aspx, 10 May 2021.

Agency for Statistics of Bosnia and Herzegovina. Demography and social statistics. Education statistics - Higher Education in 2019/2020 Academic Year, Report (Year XV, No. 2), Sarajevo, 30 October 2020.

Agency for Statistics of Bosnia and Herzegovina. Science, Technology and Digital Society, Statistics Research and Development 2019, Report, Year IX (No. 1), Sarajevo, 12 February 2021.

Babić, M. (2021). Od Srbije čekamo da nam izbroji vakcinisane. Oslobođenje [Digital Edition]. 25 May 2021. Taken from https://www.oslobodjenje.ba/vijesti/B\&H/od-srbijecekamo-da-nam-izbroji-vakcinisane-658782, 25 May 2021.

Bosnia and Herzegovina. Centre for Information and Recognition of Qualifications in Higher Education (2021). List of Higher Education Institutions. Taken from http://www.cip.gov. ba/images/pdf/ListaVSU/Lista_VSU.bos.pdf, 10 May 2021.

Bosnia and Herzegovina. Framework Law on Basics of Scientific-Research Activity and Coordination of Internal and International Scientific-Research Cooperation of Bosnia and Herzegovina. Official Gazette of Bosnia and Herzegovina No. 43/09.

Bosnia and Herzegovina. Framework Law on Higher Education in Bosnia and Herzegovina. Official Gazette of Bosnia and Herzegovina No. 59/07.

Bosnia and Herzegovina. Constitution of Bosnia and Herzegovina. [Annex IV of the General Framework Agreement for Peace in Bosnia and Herzegovina].

Bosnia and Herzegovina. Council of Ministers of Bosnia and Herzegovina (2016). Strategija razvoja znanosti u Bosni i Hercegovini 2017-2022: revidirani okvirni dokument. Taken from http://www.vijeceministara.gov.ba/akti/prijedlozi_zakona/?id=29796, 20 June 2016.

Bosnia and Herzegovina. Council of Ministers of Bosnia and Herzegovina (2020). Srednjoročni program rada Vijeća ministara B\&H 2021-2023. Council of Ministers of 
Bosnia and Herzegovina. Sarajevo. Taken from https://www.ekonsultacije.gov.ba/legislationactivities/downloaddocument?documentId=1013796, 11 June 2021.

Bosnia and Herzegovina. Council of Ministers of Bosnia and Herzegovina (2014). Odluka Vijeća ministara B\&H o postupku srednjoročnog planiranja, praćenja i izvještavanja u institucijama Bosne i Hercegovine. Official Gazette of Bosnia and Herzegovina No. 62/14.

Bosnia and Herzegovina. Council of Ministers of Bosnia and Herzegovina. Directorate for Economic Planning (2015a). Strateški okvir za B\&H. Directorate for Economic Planning Sarajevo. Taken from http://www.dep.gov.ba/naslovna/DEP\%20Strateski\%20okvir\%20 za\%20B\&H.pdf, 02 April 2021.

Bosnia and Herzegovina. Council of Ministers of Bosnia and Herzegovina. Directorate for Economic Planning (2015b). Strategy of Development of Bosnia and Herzegovina. Directorate for Economic Planning. Sarajevo. Taken from http://www.dep.gov. ba/razvojni_dokumenti/razvojna_strategija/Archive.aspx?langTag=bs-BA\&template_ id=140\&pageIndex=1, 11 June 2021.

Bosnia and Herzegovina. Council of Ministers of Bosnia and Herzegovina (2010). Strategy of Development of Bosnia and Herzegovina, Working Document. Taken from http://dep. gov.ba, 11 June 2021.

Bosnia and Herzegovina. Council of Ministers of Bosnia and Herzegovina (2016). Odluka Vijeća ministara o sistemu koordinacije procesa europskih integracija u Bosni i Hercegovini Official Gazette of Bosnia and Herzegovina No. 72/16 Taken from http://vijeceministara.gov.ba/home_right_docs/default.aspx?id=23422\&langTag=hr-HR, 11 June 2021.

Bosnia and Herzegovina. Council of Ministers of Bosnia and Herzegovina (2015). Strateški okvir za Bosnu i Hercegovinu. Taken from http://dep.gov.ba/naslovna/DEP\%2'strateski\%20 okvir\%20za\%20B\&H.pdf, 11 June 2021.

Božac, M.G. (2008). SWOT analiza i TOWS matrica - sličnosti i razlike. Ekonomska istraživanja. Vol. 21 (No. 1), pp. 20 - 23.

Consejo Superior de Investigaciones Científicas (2021). Ranking Web of Universities Bosnia and Herzegovina. Taken from https://webometrics.info/en/Europe/Bosnia\%20 and\%20Herzegovina\%20, 11 June 2021.

Cvitković, I. [ed.] (2017). Demografske i etničke promjene u B\&H, Academy of Sciences and Arts of Bosnia and Herzegovina, Sarajevo.

Čičić, M. [ed.] (2020). Studija o emigracijama Bosne i Hercegovine. Academy of Sciences and Arts of Bosnia and Herzegovina, Sarajevo.

Emirhafizović, M. \& Zolić, H. (2017). Dobna struktura i reprodukcija stanovništva Bosne i Hercegovine. [ed.] Cvitković, I. Demografske i etničke promjene u B\&H, (pp. 11-54). Academy of Sciences and Arts of Bosnia and Herzegovina, Sarajevo.

European Commission (2019). The European Charter for Researchers: The Code of Conduct for the Recruitment. Office for Official Publications of the European Communities. Luxembourg. Taken from https://www.unsa.ba/sites/default/files/inline-iles/EU\%20Povelja\%20i\%20Kodeks\%20za\%20istrazivace_BOS.pdf, 11 June 2021.

European Commission (2021). EURAXESS - Researchers in Motion. Taken from https:// euraxess.ec.europa.eu/, 11 June 2021.

Federation of Bosnia and Herzegovina. Bosnian Podrinje Canton Goražde (2015) Strategija razvoja Bosansko-podrinjskog kantona Goražde za period 2016.-2020. Godine, Taken from Http:// www. zzpr.gov.ba/bs/docs/25/4/kantonalni zzh.ba/images/PDF/Strategije/ Strategija\%20razvoja\%20Zupanije\%20Zapadnohercegovacke\%202021-2027-RADNA\%20VERZIJA.pdf -strateski-dokumenti, 11 June 2021. 
Federation of Bosnia and Herzegovina. Federal Institute for Development Programming. Uredbe. Taken from https://www.fzzpr.gov.ba/bs/docs/35/8/uredbe

Federation of Bosnia and Herzegovina. Federal Institute for Development Programming. Kantonalni strateški dokumenti. Taken from https://fzzpr.gov.ba/public/bh/strateski-dokumenti/kantonalni-strateski-dokumenti, 11 June 2021.

Federation of Bosnia and Herzegovina. FB\&H Ministry of Education and Science (2010). Strategija razvoja nauke u Federaciji Bosne i Hercegovine za period 2011 - 2021. FB\&H Ministry of Education and Science. Mostar.

Federation of Bosnia and Herzegovina. Herzegovina-Neretva Canton (2020). Strategija razvitka Hercegovačko-neretvanske županije za period 2021. - 2027. - Nacrt strateške platforme. Taken from https://www.vlada-hnz-k.ba/sites/default/files/17.11.strateska_platfroma_hnk_2021_2027_nacrt_mm_1.pdf, 11 June 2021.

Federation of Bosnia and Herzegovina. Canton 10 (2015). Strategija razvoja kantona 10 za period 2016 - 2020: Nacrt. Taken from https://www.fzzpr.gov.ba/bs/docs/25/4/kantonalni-strateski-dokumenti, 11 June 2021.

Federation of Bosnia and Herzegovina. Sarajevo Canton (2020). Strategija razvoja Kantona Sarajevo, Nacrt - proširena verzija. Taken from https://zpr.ks.gov.ba/strategija-razvojakantona-sarajevo-2021-2027strateska-platforma-nacrt-prosirena-verzija, 11 June 2021.

Federation of Bosnia and Herzegovina. Central Bosnia Canton (2016). Taken from https:// sbk-ksb.gov.ba/images/Strategija_razvoja_SBK_2016-2020.pdf, 11 June 2021.

Federation of Bosnia and Herzegovina. Tuzla Canton (2015). Nacrt strateške platforme razvoja Tuzlanskog kantona. Taken from http://www.vladatk.kim.ba/Vlada/Novosti_2014/ Nacrt_Strateske_platforme_razvoja_Tuzlanskog_kantona.pdf, 11 June 2021.

Federation of Bosnia and Herzegovina. Una-Sana Canton (2014). Integrirana strategija razvoja Unsko-Sanskog kantona, Taken from https://www.fzzpr.gov.ba/bs/docs/25/4/kantonalni-strateski-dokumenti, 11 June 2021.

Federation of Bosnia and Herzegovina. Uredba o izradi strateških dokumenata u Federaciji Bosne i Hercegovine. Official Gazette of the Federation of Bosnia and Herzegovina No. $74 / 19$

Federation of Bosnia and Herzegovina. Government of the Federation of Bosnia and Herzegovina (2020). Strategija razvoja Federacije Bosne i Hercegovine. Taken from http:// fzzpr.dgov.ba/bs/pages/48/16/strategija-razvoja-federacije-B\&H-2021-2027, 11 June 2021.

Federation of Bosnia and Herzegovina. Government of the Federation of Bosnia and Herzegovina (2021). Strategija razvoja Federacije Bosne i Hercegovine 2021-2027. Government of the Federation of Bosnia and Herzegovina. Sarajevo. Taken from http://www. sogfB\&H.ba/sites/default/files/javni_dokument/2021-05/Strategija\%20razvoja\%20 FB\&H\%202021.\%20-\%202027..pdf, 11 June 2021.

Federation of Bosnia and Herzegovina. Zakon o razvojnom planiranju i upravljanju razvojem u Federaciji Bosne i Hercegovine. Official Gazette of the Federation of Bosnia and Herzegovina No. 32/17.

Federation of Bosnia and Herzegovina. Zenica-Doboj Canton (2020). Strategija razvoja Zeničko-dobojskog kantona za period 2021 - 2027: Nacrt. Taken from https://www.zdk. ba/component/k2/item/download/5098_caae7a6c7e858099211e354ca553e6ec, 11 June 2021.

Federation of Bosnia and Herzegovina. Posavina Canton (2021). Strategija razvija Županije Posavske 2021-2027. Posavina Canton. Taken from http://www.zupanijaposavska. 
ba/wp-content/uploads/2020/11/FINALNI-NACRT-V2-Strategija-razvoja-ZupanijePosavske-10-11-2020-2_compressed.pdf, 11 June 2021.

Federation of Bosnia and Herzegovina. West Herzegovina Canton (2021). Strategija razvoja Županije Zapadnohercegovačke 2021 - 2027. Taken from http://www.eui-zzh.ba/ images/PDF/Strategije/Strategija_razvoja_ZZH_za_razdoblje_2021_-_2027_godine.pdf , 11 June 2021.

Institute for Statistics of FB\&H (2020). Projekcije stanovništva Federacije Bosne i Hercegovine 2020 - 2070. Institute for Statistics of FB\&H, Sarajevo. Taken from https://zs.ba/wp-content/uploads/2020/12/PROJEKCIJE-STANOVNI\%C5\%A0TVAFB\&H-2020_2070_bos.pdf, 11 June 2021.

Institute for Statistics of FB\&H (2020). Statistički bilten Visoko obrazovanje 2019/2020, issue 306, Sarajevo.

Institute for Statistics of FB\&H. Visoko obrazovanje u Federaciji Bosne i Hercegovine u 2020./2021. Report (Year XIII, No. 12.3), Sarajevo, 03 March 2020.

Fleisher, C. \& Bensoussan, B. (2007). Business and Competitive Analysis: Effective Application of New and Classic Methods. Pearson Education. Upper Saddle River, New Jersey. Taken from https://www.weforum.org/reports/the-global-competitiveness-report-2017-2018, 24 March 2021.

Sarajevo Canton. Government of Sarajevo Canton. Ministry of Education, Science and Youth of Sarajevo Canton (2017). Strategija razvoja obrazovanja i nauke Kantona Sarajevo za period 2018 - 2022. godine - (Nacrt). Ministry of Education, Science and Youth of Sarajevo Canton. Sarajevo. Taken from https://skupstina.ks.gov.ba/sites/skupstina.ks.gov.ba/ files/nacrt_strategije_obrazovanje.pdf, 11 June 2021.

Sarajevo Canton. Government of Sarajevo Canton. Ministry of Education, Science and Youth of Sarajevo Canton. Standardi i normativi za obavljanje djelatnosti visokog obrazovanja na području Kantona Sarajevo. Official Gazette of Sarajevo Canton No. 33/17

Kremić, E. \& Trifković, M. [ed.] (2020). Harmonizacija sistema nauke u Bosni i Hercegovini: projekt $=$ Harmonization of the science system in Bosnia and Herzegovina: project. Federalni zavod za statistiku = Institute for Statistics of the Federation of Bosnia and Herzegovina: Akademija nauka i umjetnosti Bosne i Hercegovine $=$ Academy of Sciences and Arts of Bosnia and Herzegovina. Sarajevo.

Nikolić, R. (s.a.). SWOT analiza: šta je to i kako se primenjuje. [Digital Edition]. Taken from www.issu.com/bisera.kardula/docs/1913_m_chapter_3_swor_manual_r-niko, 27 March 2021.

Pašalić-Kreso, A. (2017). Obrazovanost stanovništva u Bosni i Hercegovini - Bosna i Hercegovina između najviše stope nepismenosti i najnižeg nivoa obrazovanosti“ [ed.] Cvitković, I. Demografske i etničke promjene u B\&H, (pp. 93-124). Academy of Sciences and Arts of Bosnia and Herzegovina, Sarajevo.

Radošević, S. (2011). Science-industry links in Central and Eastern Europe and the Commonwealth of Independent States: conventional policy wisdom facing reality. Science and Public Policy. Vol 38 (No. 5), pp. 365-378.

Radošević, S. \& Lepori, B. (2009). Public Research Funding Systems in Central and Eastern Europe: Between Excellence and Relevance: Introduction to Special Section. Science and Public Policy, Vol. 36 (No. 9), pp. 659-666.

Republika Srpska. National Assembly of Republika Srpska. Materials for the $16^{\text {th }}$ Regular Session. Taken from: http://www.narodnaskupstinars.net/sites/default/files/upload/doku- 
menti/materijali_za_sjednice/lat/Materijali\%20za\%2016.\%20redovnu\%20sjednicu.zip, 26 April 2021.

Institute for Statistics of Republika Srpska (2020). Statistički bilten 2019/2020, Banja Luka, Republika Srpska. Ministry of Scientific and Technological Development, Higher Education and Information Society. Strategije. Taken from https://www.vladars.net/sr-SP-Cyrl/ Vlada/Ministarstva/mnk/PAO/Strategije/Pages/default.aspx, 11 June 2021.

Republika Srpska. Government of Republika Srpska (2017). Strategija naučnog i tehnološkog razvoja Republike Srpske 2017 - 2021. godine - Znanje za razvoj. Government of Republika Srpska. Banja Luka. Taken from https://www.vladars.net/sr-SP-Cyrl/Vlada/Ministarstva/mnk/Documents/PRIJEDLOG\%20-\%20\%20strategije \%20naucnog\%20i\%20 tehnoloskog\%20razvoja\%20RS\%202017-2021\%20\%286\%29.pdf, 11 June 2021.

Republika Srpska. Zakon o naučnoistraživačkoj djelatnosti i tehnološkom razvoju. Official Gazette of Republika Srpska No. 6/12, 33/14 66/18 and 84/19. Taken from http://spu.ba/ wp-content/uploads/2018/02/zakon_o_naucnoistrazivackoj_djelatnosti_i_tehnoloskom_ razvoju.pdf, 11 June 2021.

Republika Srpska. Zakon o visokom obrazovanju. Official Gazette of Republika Srpska No. $67 / 202$

Schwab, K. (2017). The Global Competitiveness Report 2017-2018. [Digital Edition]. World Economic Forum. Cologny/Geneva. Taken from

Schwab, K. (2019). The Global Competitiveness Report 2019. [Digital Edition]. World Economic Forum. Cologny/Geneva. Taken from http://www3.weforum.org/docs/WEF_TheGlobalCompetitivenessReport2019.pdf, 24 March 2021.

Statista (2021). Number of novel coronavirus (COVID-19) deaths worldwide as of May 24, 2021, by country. Taken from https://www.statista.com/statistics/1093256/novel-coronavirus-2019ncov-deaths-worldwide-by-country/, 24 May 2021.

Steiner, C. [et. al.] (2010). Constitution of Bosnia and Herzegovina: Commentary. Konrad Adenauer Foundation e.V.. Sarajevo.

Trifković, M. (2020a). Uticaj Dejtonskog mirovnog sporazuma na inovacioni sistem u Bosni i Hercegovini. Dijalog, 2020 (no. 3-4), pp. 40-59. ISSN 0350-6177.

Trifković, M. (2020b). Harmonizacija sistema nauke u Bosni i Hercegovini. Academy of Sciences and Arts of Bosnia and Herzegovina. Sarajevo.

Trifković, M. [ed.] (2020c). Zadržavanje mladih u Kantonu Sarajevo: analiza determinanti i prijedlog strateških mjera. Academy of Sciences and Arts of Bosnia and Herzegovina, Sarajevo.

Wikipedia (2021). List of countries by GDP (PPP) per capita. Taken from https://en.wikipedia. org/wiki/List_of_countries_by_GDP_(PPP)_per_capita, 24 March 2021.

World Bank (2021). World bank Data: Science and Technology. Taken from https://data. worldbank.org/topic/14, 26 March 2021.

World Intellectual Property Organization (2020). Global Innovation Index. Bosnia and Herzegovina. Taken from https://www.wipo.int/edocs/pubdocs/en/wipo_pub_gii_2020/ ba.pdf, 24 March 2021. 